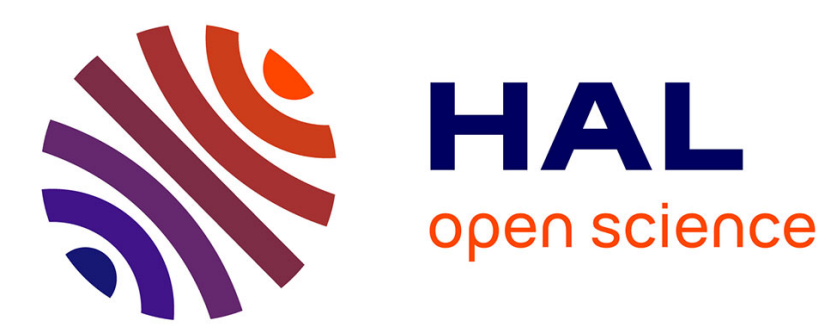

\title{
Thyroid hormones and the control of cell proliferation or cell differentiation: paradox or duality?
}

Elsa Kress, Jacques Samarut, Michelina Plateroti

\section{To cite this version:}

Elsa Kress, Jacques Samarut, Michelina Plateroti. Thyroid hormones and the control of cell proliferation or cell differentiation: paradox or duality?. Molecular and Cellular Endocrinology, 2009, 313 (1-2), pp.36. 10.1016/j.mce.2009.08.028 . hal-00522863

\section{HAL Id: hal-00522863 https://hal.science/hal-00522863}

Submitted on 2 Oct 2010

HAL is a multi-disciplinary open access archive for the deposit and dissemination of scientific research documents, whether they are published or not. The documents may come from teaching and research institutions in France or abroad, or from public or private research centers.
L'archive ouverte pluridisciplinaire $\mathbf{H A L}$, est destinée au dépôt et à la diffusion de documents scientifiques de niveau recherche, publiés ou non, émanant des établissements d'enseignement et de recherche français ou étrangers, des laboratoires publics ou privés. 


\section{Accepted Manuscript}

Title: Thyroid hormones and the control of cell proliferation or cell differentiation: paradox or duality?

Authors: Elsa Kress, Jacques Samarut, Michelina Plateroti

PII: $\quad$ S0303-7207(09)00463-8

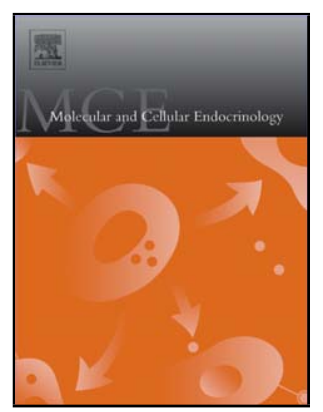

DOI: doi:10.1016/j.mce.2009.08.028

Reference: MCE 7310

To appear in: Molecular and Cellular Endocrinology

Received date:

18-5-2009

Revised date:

7-8-2009

Accepted date:

31-8-2009

Please cite this article as: Kress, E., Samarut, J., Plateroti, M., Thyroid hormones and the control of cell proliferation or cell differentiation: paradox or duality?, Molecular and Cellular Endocrinology (2008), doi:10.1016/j.mce.2009.08.028

This is a PDF file of an unedited manuscript that has been accepted for publication. As a service to our customers we are providing this early version of the manuscript. The manuscript will undergo copyediting, typesetting, and review of the resulting proof before it is published in its final form. Please note that during the production process errors may be discovered which could affect the content, and all legal disclaimers that apply to the journal pertain. 


\section{Thyroid hormones and the control of cell proliferation or cell differentiation: paradox or duality?}

Elsa Kress ${ }^{1}$, Jacques Samarut and Michelina Plateroti*

Institut de Génomique Fonctionnelle de Lyon, Université de Lyon, Université Lyon 1, CNRS, INRA, Ecole Normale Supérieure de Lyon, Lyon, France

${ }^{1}$ : Current address. Department of Genetic Medicine and Development, University of Geneva, Switzerland.

*: Corresponding Author.

Mailing address: Institut de Génomique Fonctionnelle de Lyon, Ecole Normale Supérieure de Lyon, 46 allée d'Italie, 69364 Lyon Cedex 07, France.

Tel: 33472728536

Fax: 33472728080

E-mail: Michela.Plateroti@ens-1yon.fr 


\section{Summary}

Amphibian metamorphosis perfectly illustrates a key paradox: thyroid hormones control diverse cellular processes depending on the tissue context. This point is also reinforced by a recent accumulation of evidence. For example, thyroid hormones and their nuclear receptor TRs have been described to function in different systems in synergy and/or in antagonism with other signaling pathways. This interaction helps explain their pleiotropic roles. This review summarizes the most important advances in this field, focusing in particular on the key action of thyroid hormones in controlling the balance between the processes of cell proliferation and cell differentiation in a few organs, with special attention paid to the intestine. We highlight similarities between the cellular and molecular events occurring during postnatal intestinal maturation at metamorphosis in amphibians, and comparable events observed at weaning in mice.

Key words: Thyroid hormones; Thyroid hormone Receptors 


\section{1-Introduction}

\subsection{Thyroid hormone production}

Thyroid hormones (THs), L-thyroxine or T4 and 3,5,3'-L-triiodothyronine or T3, are essential for the development of several organs, including the central nervous system, skeleton, heart, intestine, skeletal muscle and sensory organs. Moreover, they also have important regulatory effects on oxygen consumption and metabolic rate (Oppenheimer et al., 1987). The follicular cells of the thyroid gland synthesize and secrete both hormones, but T4 is the most abundant. This process is under the control of circulating THs levels through the hypothalamuspituitary-thyroid feedback regulatory loop (rev. in Fredric and Wondisford, 2004).

The intracellular concentration of T3 is dependent upon the uptake of T3 and T4, and their subsequent metabolism (Bianco and Kim, 2006). In fact, both hormones are actively transported across the cell membrane by specific transporter proteins, of which monocarboxylate transporter- 8 is the best characterized (Dumitrescu et al., 2004; Friesema et al., 2004; rev. in Refetoff and Dumitrescu, 2007 and Visser et al., 2007). Three iodothyronine deiodinase selenoenzymes (D1, D2 and D3) regulate $\mathrm{TH}$ activation and catabolism (Bianco and Kim, 2006). D1 and D2 catalyze the 5'-deiodination of T4 to its active metabolite T3. T3 is generated from the activity of D1, which is the main source of circulating T3. In contrast, D2 is the isoenzyme primarily responsible for local production of T3 in target cells. T3 derived from D2 activity in skeletal muscle may also contribute to circulating levels of T3. Conversely, D3 catalyzes the irreversible 5-deiodination of T4 and T3 to the inactive metabolites rT3 (3,5,5'-T3, or reverse T3) and 3,3'-T2, thereby protecting target cells from excess of THs, that can be deleterious especially during embryogenesis (Chassande, 2003). Thus, TH uptake and metabolism determine the levels of T3 availability into the cells.

\subsection{The Thyroid hormone nuclear Receptors}

The classical action of T3 is mediated via Thyroid hormone nuclear Receptors, the TRs, which belong to the nuclear hormone receptor superfamily of transcription factors (Laudet et al., 1992). From a molecular point of view, TRs heterodimerize with retinoid X receptors (RXRs) and bind to T3 response elements located within the genomic regions of target genes (Yen, 2001). In the absence of T3, TRs interact with co-repressor proteins to inhibit positively-regulated target gene transcription. Following T3 binding, co-repressors are displaced and co-activator proteins are recruited to the ligand-bound TR complex, so as to facilitate T3-dependent activation of the target genes. Importantly, some genes, including Thyroid-Stimulating Hormone (TSH), are inhibited by T3, but the mechanism underlying T3dependent repression of gene transcription is still poorly defined (Lazar, 2003).

TRs are encoded by the TR $\alpha$ and TR $\beta$ genes, which generate multiple isoforms by alternative promoter usage and alternative splicing (Figure 1). The TR $\alpha$ locus encodes at least four different proteins (Figure 1A), but only TR $\alpha 1$ is a true nuclear receptor. The other TR $\alpha$ isoforms, namely TR $\alpha 2$, TR $\Delta \alpha 1$ and TR $\Delta \alpha 2$ behave as antagonists of TR $\alpha 1$ (Koenig et al., 1989; Chassande et al., 1997; Plateroti et al., 2001). The TR $\beta$ locus encodes two receptors, TR $\beta 1$ and TR $\beta 2$ (Figure 1B), which differ from each other by the length of their aminotermini (Flamant and Samarut, 2003). All these isoforms are conserved between mouse and human as suggested by direct observation or comparison of respective genomic sequences. The rat THR $\beta$ locus also encodes TR $\beta 3$ and TR $\Delta \beta 3$ isoforms (Figure 1B) (Williams, 2000; Harvey et al., 2007). They can be translated separately or from a single transcript, which contains an internal TR $\Delta \beta 3$ translation start site (Williams, 2000). TR $\beta 3$ is a bona fide T3 nuclear receptor, while TR $\Delta \beta 3$ retains T3 binding ability but lacks the DNA binding domain 
and exerts a cell- and TRE-specific inhibitory function on TR $\beta 1, \operatorname{TR} \beta 3$ and TR $\alpha 1$ receptors (Harvey et al., 2007).

TR $\alpha$ and TR $\beta$ genes are widely expressed within different organs and tissues. TR $\alpha 1$ and TR $\alpha 2$ are expressed almost ubiquitously, whereas the TR $\Delta \alpha$ transcripts are found mostly in the small intestinal epithelium, lung, brain and early embryo. TR $\beta 1$ is also widely expressed and it represents the most abundant TR isoform in the liver. TR $\beta 2$ expression is restricted to the pituitary, hypothalamic TRH neurons, the developing inner ear and retina (Flamant and Samarut, 2003). The TR $\beta 3$ isoform has been described in rat liver, kidney and lung and the $\mathrm{TR} \Delta \beta 3$ in rat skeletal muscle, heart, spleen and brain (Williams, 2000).

\subsection{Membrane and cytoplasm-mediated effects of THs}

Besides the classically characterized TR-mediated functions, THs also exert rapid nongenomic actions that are initiated at the cell membrane. Data from Davis's laboratory has shown that the integrin $\alpha v \beta 3$ is a specific membrane receptor for THs, and this binding leads to activation of the mitogen-activated protein kinase (MAPK) intracellular cascade (Lin et al., 1999; rev. in Davis et al., 2008). TH-dependent MAPK activation subsequently results in a series of complex responses that occur at the cell membrane, including modulation of the membrane potential by regulation of ion channels, activation of the $\mathrm{Na}+\mathrm{K}+$ exchanger and $\mathrm{Ca} 2+-\mathrm{ATPase}$, or regulation of actin cytoskeletal components anchored at the cell membrane (Klein and Ojamaa, 2001). Moreover, TH-activated MAPK can rapidly translocate to the nucleus and induce serine phosphorylation of TRs, thereby resulting in the induction of angiogenesis or tumor cell proliferation (Davis et al., 2000). Nuclear targets for phosphorylated TRs include the transcription factors p53, STAT1a and STAT3 (Lin et al., 1999). T3 also exerts TR $\alpha$-dependent actions to regulate mitochondrial gene expression and metabolic function (Wrutniak-Cabello et al., 2000).

TR $\alpha$ and TR $\beta$ have been shown to form a cytoplasmic complex with the p85 subunit of phosphatidylinositol 3-kinase (PI3K) and induce nuclear translocation of the protein kinase B/Akt (Cao et al., 2005; Hiroi et al., 2006). Studies in TR $\beta$ PV knock-in mice, which harbor a mutation in the TR $\beta$ gene responsible for the syndrome of Resistance to Thyroid Hormones (RTH, Refetoff, 2003), showed that these mice spontaneously develop thyroid cancer and distant metastasis. This is likely due to TR-PI3K interaction and the subsequent activation of Akt (Kim et al., 2005). TR $\beta 1$ has been recently shown to inhibit the Wnt/ $\beta$-catenin pathway through its interaction, and consequent sequestration, of $\beta$-catenin in thyrocytes (Guigon et al., 2008), resulting in down-modulation of cell proliferation. In the TR $\beta$ PV knock-in mice, this interaction is abrogated because of the mutated receptor. In this setting, the Wnt/ $\beta$-catenin pathway is activated and the increased expression of its targets, as well as the stimulation of thyrocyte proliferation, correlates with the onset of thyroid cancer.

These data show that the simultaneous control by THs of PI3K/Akt and Wnt/ $\beta$-catenin pathways might have important repercussions in a TR $\beta$-mutated genetic background. Moreover, they highlight the importance of the interaction between TRs and other key signaling pathways involved in development, cellular physiology and cancer.

\section{2-Tissue-specific actions of THs and TRs}

As already mentioned, the function of THs and TRs on cell proliferation or differentiation is not homogeneous. In fact, the cell's response to THs strongly depends on the cell type, its developmental state (progenitor or differentiated), its pathophysiological state (normal or tumor cell) and, finally, the cellular context. It is worth noting that the balance between cell proliferation and cell differentiation is of fundamental importance for the control of tissue 
homeostasis. Thus, a more detailed understanding of how THs-TRs can influence this balance is of capital importance for future therapies based upon selective agonists and/or antagonists of TRs. Determining tissue-specific or generalized target genes, as well as their level of regulation (i.e., direct or indirect and early or late responsiveness) in specific cell types at defined stages will suggest how to use these compounds to turn on or off TR functions by fine tuning their transcriptional state.

To illustrate the diverse actions of THs-TRs, we decided to restrict our review to key examples. On one hand, we will focus on the nervous system, where they play an important role in controlling cell differentiation during development. We will then discuss their function in the epidermis, where their action on cell proliferation and cell differentiation is still unclear. On the other hand, we will summarize new and detailed advances in their role in promoting cell proliferation related to intestinal postnatal maturation in both tadpoles and mice.

\subsection{Nervous system}

Thyroid hormones play a major role in brain development, as it has been classically observed in thyroid-related human pathologies and described in hypothyroid and hyperthyroid animals (Nichols and Altman, 1972a; Nichols and Altman, 1972b; Nichols and Altman, 1972c; rev. in Zoeller and Rovet, 2004; Bernal, 2005; Bernal, 2007; Williams, 2008). The events controlled by THs comprise cellular proliferation, migration, and neuronal and glial cell differentiation (Narayanan and Narayanan, 1985; Berbel et al., 1993; Berbel et al., 1994; Lucio et al., 1997; Auso et al., 2004; Cuevas et al., 2005). Clinical and experimental studies have demonstrated that THs are essential for normal brain development. This was documented initially in children with congenital hypothyroidism (Leneman et al., 2001; Hindmarsh, 2002; Hrytsiuk et al., 2002; Salerno et al., 2002; Rovet and Daneman, 2003). These findings were followed by animal studies mainly focused on cerebellar development, which occurs largely postnatally (Koibuchi and Chin, 2000; Thompson and Potter, 2000; Morte et al., 2002; Singh et al., 2003). Moreover, observations in humans (Cao et al., 1994; Haddow et al., 1999; Pop et al., 1999; Pop et al., 2003) provided important evidence that THs are also essential in early (fetal) brain development, and that the associated neurological deficits depend on the timing and severity of TH insufficiency. If it occurs during pregnancy, the offspring display visual and motor problems; however, if it occurs after birth, language and memory skills are most predominantly affected (rev. in Zoeller and Rovet, 2004). These deficits depend on specific cellular impairments. Indeed, during the prenatal period, THs influence neurogenesis, neuronal proliferation and migration in the cerebral cortex, hippocampus and medial ganglionic eminence (Narayanan and Narayanan, 1985; Lucio et al., 1997; Auso et al., 2004; Cuevas et al., 2005). Axonal outgrowth, dendritic branching and synaptogenesis, together with the initiation of glial cell differentiation and migration are also affected by TH deficiency at prenatal stages (Portfield and Hendrich, 1993; Morreale de Escobar et al., 2000; Bernal et al., 2003). Hypothyroidism after birth affects cell migration in the cerebellar cortex and hippocampus. Other effects in neuronal cell differentiation include the markedly reduced dendritic arborization of Purkinje cells of the cerebellum, as well as the altered distribution of dendritic spines in the cortex and the hippocampus (Portfield and Hendrich, 1993; Morreale de Escobar et al., 2000; Bernal et al., 2003; Bernal, 2005; Bernal, 2007). Finally, another specific feature of hypothyroidism in the nervous system is the delayed and poor deposition of myelin. This defect has a profound functional effect on signal transmission and is due to impaired oligodendrocyte differentiation (Schoonover et al., 2004). Thus, depending on the developmental stage and on the severity of the hypothyroidism, the neurological features can be dramatically different. For instance, neonatal hypothyroidism has a less severe outcome then maternal-dependent $\mathrm{TH}$ deficits. However, both can be largely prevented by $\mathrm{TH}$ 
replacement, although deficits in memory and IQ may persist (Morreale de Escobar et al., 2004; Zoeller and Rovet, 2004). In the case of hypothyroidism occurring in adulthood, the neurological defects can be reverted by T4 supplementation (Ruiz-Marcos et al., 1988).

To understand the regional differences in response to alterations of TH status, it has been important to define i) where the hormone is available, and ii) the pattern of TR expression. Concerning the first, several studies have reported the regional expression of D2 and D3 deiodinases, and concluded that they have an important role in fine tuning the local availability of T3 in the developing brain. This is particularly important before the onset of thyroid gland function is fully established (Bianco and Kim, 2006). On the other hand, the availability of the THs also depends on the presence of specific transporters such as OATP1c1 and MCT8, which are both expressed in the central nervous system in astrocytes and neurons (Sugiyama et al., 2003; Tohyama et al., 2004; Heuer et al., 2005). Their importance in controlling the THs status at the cellular level was confirmed in patients with mutations in the MCT8 locus (Dumitrescu et al., 2004; Friesema et al., 2004), and was reproduced in animal models deficient for the MCT8 gene (Dumitrescu et al., 2006; Trajkovich et al., 2007). Finally, the regional availability of THs has also been demonstrated by a study in a reporter mouse expressing LacZ cDNA under the control of a synthetic TH-responsive promoter. The analysis of this model confirmed that the distribution of THs is highly dynamic and heterogeneous in the central nervous system throughout pre- and postnatal development (Quignodon et al., 2004). The authors suggested that the heterogeneity of TH signal might provide positional information to neural cells during development.

Concerning the expression of TRs, TR $\alpha 1$ accounts for a large fraction of the total receptors in the brain (rev. in Bernal, 2005; Bernal 2007). Hence, for this reason, it is thought to mediate most of the effects of THs in this organ. Interestingly, TRs are expressed early during brain development before the onset of fetal thyroid hormone production (Forrest et al., 1991). TR $\alpha 1$ is the major isoform expressed during fetal life (Forrest et al., 1991; Mellstrom et al., 1991). TR $\beta 1$ expression starts increasing before birth (Forrest et al., 1990; Forrest et al., 1991), and it is widely distributed as development proceeds (Strait et al., 1990; Mellstrom et al., 1991; Bradley et al., 1992). As previously stated, the expression of the TR $\beta 2$ isoform is restricted to the hypothalamus, anterior pituitary, developing cochlea and neural retina (Flamant and Samarut, 2003).

\subsubsection{Data from engineered mice}

The generation of TR mutants or THs-impaired mouse models has greatly expanded our knowledge of THs-TR functions in the nervous system in vivo. Loss of TR $\beta$ has a strong effect on color vision and hearing (Forrest et al., 1996), translating defects in retina M-cone differentiation and cochlea maturation, respectively (Rusch et al., 1998; $\mathrm{Ng}$ et al., 2001; Rusch et al., 2001; rev. in Fredric and Wondisford, 2004). Although these two traits are not common in congenital hypothyroidism, they have been described in RTH patients who display a large deletion of the TR $\beta$ gene (Newell and Diddie, 1977). The TR $\beta 2$ receptor is the isoform responsible for the hypothalamus-pituitary-thyroid regulatory loop that controls $\mathrm{TH}$ levels in the blood (Abel et al., 2001; rev. in Fredric and Wondisford, 2004). T3 action on both neuronal and glial lineages during brain development has been well documented. All types of glial cells are sensitive to T3 in vitro (Durand and Raff, 2000; Lima et al., 2001; Adachi et al., 2002). However, the only glial defect reported for TR $\alpha 1^{-/-}$knockout mice was a slight delay in the post-natal differentiation of the oligodendrocyte precursor cells (OPC) for the optic nerve (Billon et al., 2002) and some long term persistence of OPC proliferation in the complete absence of TRs (TR $\alpha^{0 / 0} \beta^{-/-}$mice) (Baas et al., 2002). In the latter, myelin compaction was incomplete and, as a likely consequence, retinal ganglion cells degenerated in 
some older animals. The effects of hypothyroidism on neuronal cells have been largely studied in the cerebellum during the second week of post-natal development. In the external granular layer (EGL), neuroblast proliferation, survival and migration are reduced, which results in a transient thickening of the EGL. The underlying Purkinje cell layer also displays limited dendritic arborization. Surprisingly, no major defect in cerebellar histology has been reported for single and double TR knockout mice. More recent studies have demonstrated that although T3 is able to positively regulate the expression of some genes (Morte et al., 2002; Potter et al., 2002), it acts mainly by reversing the negative effect of unbound TR $\alpha 1$ receptor in EGL cells. This conclusion is consistent with the observation that the cerebellum of TR $\alpha 1^{-/-}$ mice does not display the typical histological features of hypothyroidism, even when the T3 level is reduced by drug treatment (Morte et al., 2002). Until recently, the status of TR $\beta$ in the cerebellum was less clear, and it seems that only one out of two knock-in mutations made in mice had severe consequences on cerebellar development (Kaneshige et al., 2000; Hashimoto et al., 2001). The reasons for this apparent discrepancy remain unknown. In cerebellum, TR $\alpha 1$ is expressed in granular cells whereas both TR $\alpha 1$ and TR $\beta 1$ are present in Purkinje cells. Accordingly, T3 acts via TR $\alpha 1$ to regulate granular cell migration, and via TR $\alpha 1$ and TR $\beta 1$ to control Purkinje cell differentiation (Morte et al., 2002). Moreover, a novel action of THs and TRs on the maturation of cerebellar GABAergic interneurons from their Pax2expressing precursors has been recently described (Manzano et al., 2007a). These interneurons are generated in the subventricular zone of the embryonic fourth ventricle from where they migrate to the cerebellum. Hypothyroidism causes both decreased proliferation and delayed differentiation of the GABAergic precursors. Both TR $\alpha 1$ and TR $\beta$ mediate this maturation process (Manzano et al., 2007a), through a mechanism that likely involves cellcell interactions. In fact, cerebellar astrocyte maturation is severely impaired in hypothyroid rats (Manzano et al., 2007b) and in TR $\alpha 1$-deficient mice (Morte et al., 2004). On the other hand, GABA also has a trophic function and influences astrocyte morphology and maturation (Runquist and Alonso, 2003). In the paper by Manzano (Manzano et al., 2007a), it was speculated that both the astrocytic and GABAergic interneuron maturation processes may be interrelated. Indeed, impaired astrocyte maturation could be secondary to altered GABAergic interneuron differentiation. Conversely, proliferation of Pax2-expressing precursors and the subsequent migration and differentiation could be influenced by trophic factors from surrounding astrocytes. Future advances in this field will surely arise from the development of cell-type specific mutant mice for TR $\alpha$ and/or TR $\beta$ genes. These mice would then provide powerful tools for a detailed analysis of instructive cell-cell interactions during development.

Genetically engineered mice also helped to analyze the function of TRs on behavior. A TR $\beta$ dominant-negative mutation in the mouse was responsible for an attention deficit and hyperactivity disorder (Wong et al., 1997). Importantly, this condition also occurs in human RTH patients (Refetoff, 2003). Mating can also be influenced by mutations in TRs (Dellovade et al., 2000). The role of the TR $\alpha 1$ receptor on behavior also came from a study on a TR $\alpha 1$ knock-in mouse model (Tinnikov et al., 2002). The mutation introduced into the gene allows the receptor to be unable to modulate gene transcription, thereby resulting in animals with minor disturbances in $\mathrm{TH}$ homeostasis, but major aberrancies in postnatal development, psychomotor behavior and metabolism. Even if a similar mutation has never been reported in the TR $\alpha$ gene of RTH patients, these parameters are similar to those seen in endemic cretinism and untreated congenital hypothyroidism.

\subsubsection{Gene regulation}

According to the nuclear pathway of action of thyroid hormones, most of the effects on nervous system developmental processes are carried out through the control of gene 
expression. These genes include the myelin genes in oligodendrocytes (Sutcliffe, 1988; Schoonover et al., 2004), glial fibrillary acidic protein and vimentin expression in astrocytes (Lima et al., 1998), extracellular matrix proteins and adhesion molecules involved in neuronal migration and differentiation and in axonal growth, guidance and fasciculation. These adhesion molecules include tenascin C, laminin, L1 and NCAM (Iglesias et al., 1996; Alvarez-Dolado et al., 1998; Farwell and Dubord-Tomasetti, 1999a; Farwell and DubordTomasetti, 1999b; Alvarez-Dolado et al., 2000). THs also control the expression of many proteins that have roles in terminal cell differentiation, including cell cycle regulators, cytoskeletal proteins, neurotrophins and neurotrophin receptors. Among the cell cycle regulators, THs regulate the expression of E2F1, p53, cyclins and cyclin-dependent kinase inhibitors (Perez-Juste and Aranda, 1999; Qi et al., 1999; Wood et al., 2002). However, the regional and temporal patterns of in vivo regulation and the cell types in which such regulation is relevant are unknown with the exception of the implication of E2F1 in oligodendrocyte differentiation (Nygard et al., 2003). Finally, THs influence the expression of cytoskeletal components, important mediators of morphological differentiation, as well as axonal and dendritic outgrowth (Silva and Rudas, 1990; Aniello et al., 1991a; Aniello et al., 1991b; Lorenzo et al., 2002). Only in a few examples has it been possible to assign the control of gene expression to a specific receptor subtype (Calza et al., 2000; Abel et al., 2001; Quignodon et al., 2007; Diez et al., 2008). Finally, a recent study identified the TR $\beta 1$ binding sites and target genes in the developing mouse cerebellum through the use of the ChIP-onChIP technology (Dong et al., 2009). This is the first report of a large-scale approach to identify direct THs gene targets in the developing mouse brain, and provides a first glimpse at the specific gene targets in the cerebellum. A similar analysis of TR $\alpha 1$ binding sites on chromatin will highlight the differences and/or similarities of their respective target genes. The final goal would be to define a TR-subtype-specific signature of target genes in the developing cerebellum.

\subsubsection{Postnatal neurogenesis}

Recent findings on postnatal neurogenesis have also described the importance of $\mathrm{TH}$ signaling. Indeed, chemically-induced hypothyroidism in the juvenile and adult rat dentate gyrus and hippocampus decreases neuronal stem/progenitor cell proliferation and survival. Molecular analysis has shown that a deregulation of several signaling pathways important for neurogenesis such as FGF and Wnt was the basis for the phenotype (Zhang et al., 2009). An in vitro model of human neuronal progenitors can be induced to differentiate by THs. In fact, treatment with $\mathrm{TH}$ increases the expression levels of the selective Alzheimer's disease indicator-1 (seladin-1), which displays neuroprotective properties and is down-regulated in brain regions affected by Alzheimer's disease. Subsequently, through the regulation of seladin-1, T3 has been demonstrated to prevent chemically-induced apoptosis (Benvenuti et al., 2008). These data strongly suggest a potential therapeutic use of THs in Alzheimer's disease. Adult neural stem cells of the subventricular zone (SVZ) in mouse also require THs and TR $\alpha 1$ function (Lemkine et al., 2005). In these cells in vivo, THs-TR $\alpha 1$ likely act to inhibit the expression of c-Myc and cyclin D1, inducing their exit from the cell cycle. Indeed, in the SVZ, TH deficiency results in an abnormal accumulation of proliferating BrdU-positive cells, which is indicative of a failure to re-enter the cell cycle. Similarly, the absence of TR $\alpha$ has also been shown to block cell cycle progression. Taken together, these findings suggest the importance of the cellular environment on the physiology of adult stem cells. Obviously, more detailed analyses are needed to clearly define the mechanisms controlling postnatal neurogenesis. However, from the data summarized, THs-TRs will surely represent interesting and promising candidates for future developments in this field. It is worth noting that both cyclin D1 and c-Myc, which are down-regulated by THs-TR $\alpha 1$ in SVZ stem/progenitors, are 
also well known targets of the Wnt/ $\beta$-catenin pathway in other tissue contexts (Clevers, 2006), thereby raising the question of the importance of a possible crosstalk between TR and the Wnt pathway in the nervous system. More importantly, it is well established that the development of the nervous system is dependent upon multiple integrated signals that contribute to various processes during development, as well as in adult neurogenesis (Duan et al., 2008). The crosstalk between TR and the Wnt/ $\beta$-catenin pathway has been described in mouse intestinal epithelium and will be discussed in the next section of this review. Concerning the nervous system, there are only a few reports that describe the regulation of the Wnt/ $\beta$-catenin pathway by THs. In a pituitary cell model, TH-TR $\beta 1$ negatively controls the expression of several components of the Wnt/ $\beta$-catenin pathway (Miller et al., 2001). As already mentioned, in rat neuronal progenitors, the levels of THs have an effect on Wnt3a expression and on the size of the pool of these progenitors in specific regions of the nervous system (Zhang et al., 2009).

In summary, from these different studies it is clear that THs and TRs play an important role in the nervous system in controlling cell proliferation and cell differentiation during development. Lower levels of THs block cell maturation through the maintenance of cycling cells. In agreement with this assumption, the expression of cell cycle positive and negative regulators are increased or decreased, respectively, in the hypothyroid condition (rev. in Bernal, 2005). Moreover, new and promising studies have implicated their role in adult neurogenesis and neuronal survival in diseases such as Alzheimer's.

\subsection{Skin}

The skin pathologies associated with thyroid dysfunction are well known. In fact, the term myxedema, the original name for hypothyroidism, refers to the edema like-associated skin condition caused by increased glycosaminoglycan deposition in the skin (Ord, 1878), which was subsequently connected to alterations in TH status (Horsley, 1885).

The skin in mammals constitutes a barrier against the external environment (Blanpain and Fuchs, 2006; Koster and Roop, 2007). Once mature, the epidermis undergoes homeostatic regulation as basal cells periodically execute their program of terminal differentiation and move outwards in a columnar fashion. The basal to suprabasal (or spinous) transition represents the first step through terminal differentiation. As cells enter the spinous layer, they mark a territory of the stratified squamous epithelia that possess proliferative potential (Blanpain and Fuchs, 2006; Koster and Roop, 2007). The keratin genes encode epithelialspecific intermediate filaments, making up about $30 \%$ of the protein of the epidermis. The following associations between the keratin genes and specific phases of skin growth have been made (Freedberg et al., 2001): keratins 1 and 10 have been associated with epidermal differentiation; keratins 6, 16, and 17 have been associated with epidermal proliferation and wound repair; keratins 5 and 14 are expressed in the basal skin layer and their expression decreases as the skin cells differentiate.

\subsubsection{Function of THs in development and homeostasis}

A few reports have indicated roles for THs in the regulation of epidermal differentiation during fetal rat skin development (Komuves et al., 1998). Accordingly, hypothyroidism in mice delays the development of the stratum corneum (Hanley et al., 1998). Related to the action of THs, TRs are expressed in most of the cell types composing the epidermis, as shown by mRNA or protein analysis (Torma et al., 1993; Billoni et al., 2000; Torma et al., 2000). Finally, as described for the nervous system, a complex expression pattern for deiodinase among different cell types has been reported to account for the local availability of T3 (Bianco and Kim, 2006). 
The function of THs in controlling the balance between cell proliferation and cell differentiation in the skin has proven to be puzzling. In fact, reports have indicated that they are essential for optimal epidermal cell proliferation (Safer et al., 2003; Safer, 2005). In vitro, T3 stimulates keratinocyte proliferation. In vivo, topical T3 stimulates epidermal proliferation, dermal thickening and hair growth (Safer et al., 2001; Safer et al., 2003; Safer, 2005). Topical triac (tri-iodothyroacetic acid) thickens skin by stimulating the production of collagen (Faergemann et al., 2002; Yazdanparast et al., 2004). However, TH effects on skin depend on the route of delivery. In contrast to the effects seen with topical T3, systemically induced thyrotoxicosis in rodents results in the skin thinning and hair loss (Safer et al., 2003), along with associated collagen loss (Fink et al., 1967). Recent findings have shown that hypothyroidism in mice retards wound healing relative to euthyroidism (Safer et al., 2004; Safer et al., 2005). In contrast, prior reports examining the effects of THs on wound healing have been contradictory, even when THs were administered similarly (Lennox and Johnston, 1973; Zamick and Mehregan, 1973; Mehregan and Zamick, 1974; Erdogan et al., 1999). Ambiguities have also resulted from studies on keratin expression. Although THs stimulate the levels of keratins 6, 16, and 17, which are associated with cell proliferation (Safer et al., 2004), only negative thyroid hormone response elements have been identified for these genes to date (Tomic et al., 1990; Ohtsuki et al., 1992). Nevertheless, the expression of keratin 6 at the protein level is diminished in hypothyroidism and is dramatically stimulated with supraphysiologic doses of THs (Safer et al., 2004), thereby strongly suggesting that its stimulation by THs might be indirect. The contradictory results obtained by systemic and topical administrations of $\mathrm{THs}$ in keratinocyte proliferation during both homeostasis and wound healing remain hard to explain. However, it is possible that by systemic administration, some yet undefined antiproliferative factors may be stimulated by THs that act indirectly on the skin. This would result in a mitigated responsiveness to the exogenous THs. It is worth noting that there are no reports addressing TR-modified animals concerning the action on epidermis. The use of such models could surely help explain and/or resolve some of these contradictions.

\subsubsection{Crosstalk between THs and Sonic Hedgehog}

As already mentioned for the nervous system, TH action on the epidermis is dependent on the relative intracellular concentration of $\mathrm{T} 3$. This relative availability can be a influenced by systemic delivery, T3 metabolism by keratinocytes themselves or by adjacent dermal fibroblasts (Bianco and Kim, 2006). Altogether, these processes fine tune the amount of T3 available for cellular and molecular action. Mouse genetics have identified multiple signaling pathways that are essential for proper epidermal stratification and for the acquisition of the skin barrier function (Blanpain and Fuchs, 2006). The interplay between these signaling pathways and transcription factors is beginning to emerge. This interplay comprises a crosstalk between sonic hedgehog (Shh) and the thyroid hormones (Bianco, 2008). The Shh pathway determines patterns of cell growth and differentiation in a wide variety of developmental and disease processes, including cancer, as well as in continuously remodeling organs such as skin (Briscoe and Therond, 2005). Recent findings suggest that Shh might control THs action in the epidermis by affecting the balance between $\mathrm{TH}$ inactivating (D3) and activating (D2) deiodinases, which could then be critical in modulating the balance between proliferation and differentiation of keratinocytes (Dentice et al., 2007). Shh is known to be overactive in basal cell carcinomas (BCCs) and related skin tumors (Briscoe and Therond, 2005). Dentice et al. (Dentice et al., 2007) have shown that D3 was significantly over-expressed in two BCC cell lines derived from Gli2N-expressing transgenic mice and in human BCC samples versus surrounding normal skin. This regulation represents a route by which Shh exerts its proliferative effects by attenuating THs signaling. These observations 
clearly indicate a function for THs in blocking cell proliferation through its local inactivation. These observations contrast with the described positive action of topical TH delivery on cell proliferation. Considering this last piece of evidence, the following complex regulatory loop would exist in skin: Shh-responding cells upregulate D3 deiodinase, which depletes the environment of $\mathrm{T} 3$, thereby resulting in the activation of cell proliferation. It remains to be established whether Shh itself is a target of THs in epidermal cells as it has been shown to be in intestinal epithelium during TH-dependent amphibian metamorphosis (Ishizuya-Oka et al., 2001; rev. in Ishizuya-Oka et al., 2008). This last possibility suggests a supplementary regulatory loop that might explain the contradictory results described so far. We can hypothesize that the final cellular outcome (i.e., proliferation or differentiation) might depend on both the intracellular levels of T3 and on the degree of Shh activation.

\section{3-Tissue-specific action of THs and TRs in the intestine}

THs and TRs modulate cell proliferation through the modification of expression of different genes/proteins involved in cell cycle control: growth factors (such as EGF and TGF- $\beta$ ), cell surface receptors (e.g., EGFR), as well as proteins acting at the cell membrane (e.g., Ras), various transcription factors (c-Fos, c-Myc and E2F1), cyclins, Cip/Kip family of cdk2 inhibitors and the p53 inhibitor Mdm2. Moreover, it has also been shown that TRs can form complexes with other transcription factors such as p53, which is itself a key regulator of apoptosis and proliferation (Puzianowska-Kuznicka et al., 2006). As already reported, the cellular response to $\mathrm{TH}$ can be highly heterogeneous. However, it has been clearly demonstrated that in several organs of the gastrointestinal tract, THs-TRs stimulate cell proliferation. This effect has been documented in rat liver and pancreas (Ledda-Columbano et al., 2005; Columbano et al., 2006), as well as in renal proximal tubular epithelial cells (Ohmura et al., 1997). Indeed, THs activate proliferation of hepatocytes after partial hepatectomy and are, in fact, considered primary liver mitogens (Francavilla et al., 1994; Malik et al., 2003; Alisi et al., 2005; Bockhorn et al., 2007). Detailed studies have described the target genes, as well as the involvement of the TR $\beta 1$ receptor in mediation of this function in liver (Pibiri et al., 2001; Columbano et al., 2006). In addition, data from our laboratory has described the action of THs in stimulating intestinal epithelial progenitor proliferation. They are detailed in the following section.

\subsection{Focus on intestinal epithelial progenitors}

This section summarizes data on the actions of THs-TRs in the intestine by comparing the cellular and molecular events responsible for stimulation of cell proliferation during postnatal maturation. Since the first detailed analysis was originally performed in amphibians during metamorphosis, we will start by reviewing data in this vertebrate. Next, we will illustrate advances in mouse intestine maturation at weaning.

The first clues for a role of thyroid hormones in the regulation of cell proliferation came from observations of amphibian metamorphosis at the beginning of the 20th century. Metamorphosis is strictly and exclusively controlled by THs. Three types of changes take place during this process: complete involution of some organs, remodeling of others, and de novo development of new ones. On the cellular level, these changes are caused by a combination of apoptosis and cell proliferation (Su et al., 1999; rev. in Brown and Cai, 2007). During the process of amphibian metamorphosis, the gastrointestinal tract undergoes a dramatic remodeling, which comprises a first phase of apoptosis and then a burst in cell proliferation. 


\subsubsection{TH-mediated intestinal remodeling in amphibians}

The amphibians develop in two steps: the herbivorous aquatic tadpoles hatch from the eggs and then mature into carnivorous and semi-aquatic adult frogs. The metamorphosis allows the transition from the tadpole stage to the frog, and the remodeling of several organs, including the intestine. This remodeling allows the animal to adapt to adult life.

The intestinal mucosa in tadpoles is composed of larval epithelial cells from an endodermic origin, which are associated with connective tissue and muscle layers (Brown and Cai, 2007). The larval epithelium is organized in a monolayered flat sheet of differentiated cells and presents as one single fold, the typhlosole, which spans through the first third of the intestine (Figure 2A). This epithelium is maintained by the presence of a few randomly distributed proliferating cells (Marshall and Dixon, 1978; rev. in Ishizuya-Oka and Shi, 2005). Remodeling of the intestine starts at the climax of metamorphosis with the first step occurring in the lamina propria. This layer is composed of extracellular matrix proteins located between epithelial and mesenchymal cells (Ishizuya-Oka and Shi, 2005). Under the actions of increasing levels of THs and TR $\beta$, the lamina propria becomes thicker and permeable. This permeability has two consequences: the first is that the larval epithelial cells lose their contact with the protein composing the lamina, and the second is that large numbers of cells undergo apoptosis. However, the permeability of the lamina propria allows a few epithelial cells to establish contact with sub-epithelial fibroblasts, thereby protecting the epithelial cells from apoptosis. It is from these larval epithelial cells, which are resistant to apoptosis, that the primordia of adult epithelial cells will be derived. Accordingly, these primordia are localized between the residual epithelia and the connective tissue. Finally, they proliferate very rapidly to replace the degenerating larval epithelium (Ishizuya-Oka and Shi, 2005). These islets of primordia then invaginate into the connective tissue so that the mature adult epithelium starts to be functionally organized and forms folds (Figure 2B). The proliferative cells are located in the interfold region, and the differentiated cells are located in the folds. From this stage onward, the epithelium is constantly renewed along the trough-crest axis (Ishizuya-Oka and Shi, 2005), which strongly resembles the mammalian intestine (Figure 2F). It is worth noting that for a long time, the origin of the adult epithelial progenitor cells or stem cells was not clearly defined (Ishizuya-Oka et al., 2003; Schreiber et al., 2005). Interestingly, a recent study has now demonstrated that they arise from dedifferentiated larval epithelial cells under the influence of the THs (Ishizuya-Oka et al., 2009).

The cascade of events at the basis of the larval-to-adult epithelial transition has been demonstrated to be entirely regulated by THs. The TR $\beta$ gene is ubiquitously upregulated by the increasing levels of circulating THs, which signals the beginning of metamorphosis (Shi and Ishizuya-Oka, 1997). TR $\beta$ is highly expressed in larval epithelial cells just before the onset of apoptosis, and then its level decreases. TR $\beta$ is also expressed in the proliferative adult epithelial cells as soon as they are histologically visible in the primordia, but decreases when they start to differentiate (Shi and Ishizuya-Oka, 1997). TR $\beta$ has been implicated in both apoptosis and proliferation during metamorphosis. As stated above, the lamina propria in the tadpole intestine undergoes a drastic restructuration during metamorphosis. The detailed mechanisms for this are still poorly understood. However, one hypothesis is that the shortening of the intestine, due to massive apoptosis, triggers contractions and thickening of the lamina (Ishizuya-Oka and Shi, 2005). However, the increased permeability described above can only be possible because of changes in protein composition. In this respect, it has been shown that the stromelysin 3 (ST3) gene, which belongs to the matrix metalloprotease (MMP) family of proteins, is a target of THs and TR $\beta$ in the intestine (Fu et al., 2006). Moreover, blocking the catalytic activity of ST3 by antibodies within in vitro organ cultures inhibits TH-induced metamorphosis (Ishizuya-Oka et al., 2000). In contrast, its overexpression triggers permeabilization of the lamina propria and apoptosis of the larval 
intestinal epithelial cells even in the absence of THs (Fu et al., 2005). This clearly indicates that ST3 induction by THs is a key step in intestinal metamorphosis. In vitro cultures of tadpole intestinal epithelium have shown that the larval-to-adult transition needs contact between epithelial and mesenchymal cells (Shi and Ishizuya-Oka, 1996; rev. in Ishizuya-Oka and Shi, 2005). The dialogue between theses cell types is mainly mediated by Sonic Hedgehog (Shh) and BMP4 (rev. in Ishizuya-Oka and Hasebe, 2008). Interestingly, Shh is an early-induced target of THs (Stolow and Shi, 1995). Moreover, Shh is highly expressed in adult epithelial primordia and decreases when differentiation markers such as intestinal fatty acid binding protein (IFABP) start to be expressed (Shi and Hayes, 1994). Shh induces cell proliferation of both adult epithelial primordia and sub-epithelial fibroblasts (Ishizuya-Oka et al., 2001). In the later cell type, Shh activates the expression of BMP4, which in turn plays a double role: it represses fibroblast proliferation through an autocrine loop, and induces differentiation of adult epithelial cells via a paracrine action (Ishizuya-Oka et al., 2006; rev. in Ishizuya-Oka and Hasebe, 2008). The Hedgehog interacting protein (Hip) is an inhibitor of Shh and has recently been identified as one of the mediators of this complex epithelialmesenchymal regulatory loop (Hasebe et al., 2008). It is worth noting that a functional interaction between Hhs and BMPs in mammalian intestine has also been described (reviewed in Rubin, 2007), and that this involves instructive epithelial-mesenchymal interactions. This underlies the existence of a similar regulatory loop in different genders of vertebrates.

A paper by Shi's laboratory recently reported a genome-wide analysis of the intestine during its remodeling at metamorphosis (Buchholz et al., 2007). They analyzed early and late stages after $\mathrm{TH}$-induced intestinal remodeling and also compared the transcriptional programs triggered by THs at one specific stage in different organs such as brain, limb, tail and intestine. Interestingly, they found changes in only a restricted core of common target genes, since most of the TH-controlled genes display a tissue-specific signature (Buchholz et al., 2007). This finding is very consistent with the diversified responses to THs among different organs during metamorphosis. It is worth noting that by comparing this study with the one by Kress et al. (Kress et al., 2009), it is possible to reveal a consistent number of common target genes in the developing intestine of both Xenopus and mouse.

\subsubsection{Mouse intestinal development and homeostasis}

The mouse embryonic gut tube is composed of a pluristratified endoderm, which eventually gives rise to a monolayered epithelium, and of a mesenchyme that generates the connective and smooth muscle tissues (Rubin, 2007). The developmental changes during the endodermto-intestinal epithelium maturation are achieved through three major morphogenetic and differentiation steps that lead to the remodeling of the primitive gut: 1) villus formation during fetal life; 2) intestinal crypt formation soon after birth; and 3) the final maturation at weaning, which allows the animal to adapt from milk to a solid diet (Henning et al., 1994). These phases of intestinal maturation are schematized in Figure $2(\mathrm{D}-\mathrm{H})$. Starting from the stage of villus formation, the intestinal epithelium is functionally compartmentalized in the villus epithelium, where the differentiated cells are located, and in the intervillus/crypt epithelium, where proliferation takes place (Rubin, 2007). Another peculiarity of the intestinal epithelium is its continuous cell renewal fuelled by multipotent stem cells within the crypts. The epithelial cells acquire differentiated phenotypes during their migration, whereupon they finally die and are exfoliated into the lumen (Rubin, 2007). Figure 3 summarizes these features. The thickness of the small intestine mucosa depends on the rate of crypt cell division and migration, as well as the lifespan of the villus cells. All these parameters change markedly during normal development and in response to various environmental, dietary and hormonal factors (Henning et al., 1994). 
Although several data emphasize the autonomous developmental properties of the gut, it is well known that its preweaning development also depends on various growth and hormonal factors (Henning et al., 1994). A role for THs during intestinal postnatal maturation at weaning in rodents has been suggested because their circulating concentrations increase significantly during the second postnatal week (Hadj-Sahraoui et al., 2000). At that time, structural and functional remodeling takes place, and THs have been shown to stimulate extensive mucosal growth and initiate the onset of adult-type digestive enzymes of the absorptive enterocytes (Henning et al., 1994). However, there is only limited data describing the function for THs on adult intestinal physiology, including metabolic processes such as the absorption and secretion of nutrients (Henning et al., 1994; Jumarie and Malo, 1994; MatosinMatekalo et al., 1999). Currently, the functions of THs in the early gut embryo or fetal development have not been clarified.

\subsubsection{Data from engineered mice}

The generation of animal models has provided great insights into our understanding of the function of THs and TRs in the intestine. Our laboratory has participated in developing such mouse models (Flamant and Samarut, 2003), and we have also used the congenital hypothyroid $\mathrm{Pax}^{-/-}$mice (Mansouri et al., 1998). They represented powerful tools to study in detail and to characterize the molecular mechanisms by which the TH pathway affects postnatal intestinal development. It is worth pointing out that almost all the TR isoforms are expressed by intestinal epithelial cells (Plateroti et al., 1999; Plateroti et al., 2001). These animal models also enabled us to define the specificity of each TR isoform. The small intestine from the different TR and Pax 8 knock-out animals has been analyzed to reveal histological, proliferation and differentiation defects in the epithelial cells. Furthermore, this analysis has been performed on animals aged 2-3 weeks in order to recapitulate the maturation process at weaning. This comparative study led to the following conclusions:

- THs control the proliferation of the crypt epithelial progenitors during maturation at weaning. This function depends on the TR $\alpha 1$ receptor (Gauthier et al., 2001; Plateroti et al., 2001; Flamant et al., 2002) and involves the transcriptional regulation of cell cycle control genes and of the Wnt/ $\beta$-catenin pathway (Plateroti et al., 2006; Kress et al., 2009) (detailed in the next paragraph);

- There is no redundancy between the TR $\alpha$ and the TR $\beta$ genes, at least for the functions analyzed (Plateroti et al., 1999);

- The natural truncated isoform TR $\Delta \alpha$ negatively controls epithelial cell proliferation and differentiation. This results from its repressor activity, independent of THs, on the cdx 1 and cdx2 genes (Plateroti et al., 1999; Plateroti et al., 2001). The products of these homeobox genes specifically control intestinal epithelial proliferation and differentiation (Freund et al., 1998);

- The different effects of the TR $\alpha$ isoforms depend on the level of their respective expression. For instance, the TR $\Delta \alpha$ proteins are destabilized by the TR $\alpha 1$ receptor through a mechanism involving their degradation by the proteasome pathway (Gauthier et al., 2001). On the other hand, the TR $\alpha 1$ receptor responsiveness to T3 can be blocked by the TR $\Delta \alpha$ proteins (Plateroti et al., 2001).

Together, these observations lead to a model (Figure 4) in which the different isoforms encoded by the TR $\alpha$ gene interact during intestinal maturation at weaning. The TR $\alpha$ gene encodes positive (TR $\alpha 1)$ and negative $(\mathrm{TR} \Delta \alpha)$ regulators of epithelial proliferation. Their expression has to be strictly controlled to guarantee normal mucosa growth and functionality. 


\subsubsection{Crosstalk between THs-TR $\alpha 1$ and $\mathrm{Wnt} / \beta$-catenin}

Understanding in detail the molecular mechanisms of THs-TR $\alpha 1$ function in intestinal epithelial progenitor proliferation, has represented a major challenge of our recent studies. As previously stated, we have shown that THs-TR $\alpha 1$ control the expression of components of the Wnt/ $\beta$-catenin pathway. This pathway is considered a key signaling modulator of physiological and pathological cell proliferation in the intestinal epithelium (Clevers, 2006). Moreover, due to its direct action on epithelial stem cells, it is also a main regulator of epithelial homeostasis (Clevers, 2006). The extracellular Wnt signal is transduced by its binding to the transmembrane frizzled receptor, thereby resulting in the stabilization of $\beta$ catenin and the activation of Tcf/ $\beta$-catenin target genes (Figure $5 \mathrm{~A}$ ). Our studies have shown that the TR $\alpha 1$ receptor is a direct transcriptional regulator of the Ctnnb1 gene, which encodes $\beta$-catenin. The increased expression of $\beta$-catenin, in turn, activates its targets such as cyclins D1 and D2, as well as c-Myc (Plateroti et al., 2006), which are all positive regulators of cell proliferation (Chandrasekaran et al., 1996; van de Wetering et al., 2002; Lynch et al., 2003). In order to analyze the THs-responsive genes in more detail, we used a global comparative transcription profile approach on laser microdissected intestinal crypt cells from animals before they were weaned. This approach allowed us not only to compile a comprehensive list of target genes in these cells, but also to define the crosstalk between THs-TR $\alpha 1$ and other signaling pathways that control epithelial cell homeostasis (Kress et al., 2009). One of the major results described in this analysis was the characterization of a new direct target of $\mathrm{TR} \alpha 1$, the secreted frizzled-related protein sFRP2, which is another component of the Wnt/ $\beta$ catenin pathway (rev. in Bovolenta et al., 2008). Interestingly, in intestinal progenitors in vitro, it behaves as a positive regulator of the canonical Wnt pathway by stabilizing $\beta$-catenin (Kress et al., 2009). Altogether, our previous and more recent results have indicated a key role of TH signaling in intestinal epithelial progenitors through direct and simultaneous control of several components of the Wnt/ $\beta$-catenin pathway. In accordance with other reports (Bafico et al., 1999; Cho et al., 2008), our results have shown that the action of sFRP2 involves the frizzled receptors. These data strongly suggest that the stabilization of $\beta$-catenin might be achieved through the classical pathway. Then, as schematized in Figure 5B, in intestinal epithelial progenitors, THs-TR $\alpha 1$ increase the expression of both $\beta$-catenin and sFRP2. Increased levels of sFRP2 protein in the extracellular milieu allow stabilization of $\beta$-catenin through the interaction with frizzled alone or in combination with Wnt. This results in stimulation of epithelial progenitor proliferation. It is worth pointing out that the actions of sFRPs on Wnt/ $\beta$-catenin have been described in contradictory terms: both in activation and inhibition (rev. in Bovolenta et al., 2008). Then, even if we could demonstrate a positive action of sFRP 2 on the stabilization of $\beta$-catenin, the precise mechanism of this process needs to be characterized. Finally, our analysis also indicated that in addition to Wnt, also Notch and BMP, other key signaling pathways involved in intestinal development and homeostasis (Brittan and Wright, 2004), were regulated by alteration of THs levels (Kress et al., 2009). This indicates that via the complex modulation of signaling pathways, some by direct transcriptional control ( $\beta$-catenin and sFRP2) and others by indirect cell-cell mediated interactions (Notch1 and BMP7, our unpublished observations), THs-TR $\alpha 1$ contribute to the process of intestinal maturation and to its homeostatic control.

\subsubsection{Parallels between amphibians and mouse}

As already noted, mouse intestinal maturation at weaning and tadpole intestinal remodeling at metamorphosis share several similarities. First of all, both are under the influence of increasing levels of circulating THs. Moreover, it is interesting to note that THs control 
proliferation of epithelial cells in both species, and that this correlates with a set of common TH-regulated target genes (Table 1). Finally, this maturation process allows in both cases an extensive growth of the intestinal mucosa. However, a major discrepancy is the fact that the stimulation of cell proliferation by THs in mouse intestine principally involves the $\mathrm{Wnt} / \beta$ catenin pathway. The regulation of Notch and BMP has been less studied. On the other hand, the Hedgehog signaling pathway seems to be the first target of THs in tadpoles. In the mouse, the Hedgehog pathway is critical to maintain the crypt-villus homoeostasis (Brittan and Wright, 2004). However, we found only a marginal regulation of Hh by THs in our genomewide analysis performed on 2-week old mice, which corresponds to an intestinal developmental stage highly sensitive to TH status (Plateroti et al., 2001; Plateroti et al., 2006). On the other hand, it is striking to observe that the Wnt/ $\beta$-catenin pathway, which is so fundamental for the regulation of development and for the homeostasis of mouse intestinal epithelium, seems to play a minor role in Xenopus intestinal physiology. It is worth noting that in the paper by Bucholz (Buchholz et al., 2007), several components of the Wnt pathway, including $\beta$-catenin and sFRP2, were up-regulated by THs in the intestine. Thus, it is possible that future analyses will describe specific functions of $\mathrm{Wnt} / \beta$-catenin in tadpole intestinal remodeling during metamorphosis.

\section{Concluding remarks}

In this review, we summarized and integrated data on the pleiotropic roles of THs-TRs in different tissues and animal contexts. In spite of our detailed knowledge, their functions still appear to be puzzling when we move from one cellular context to another. Indeed, the diverse actions of THs on the organ targets depend on the following criteria: i) the specific TR expression, ii) local transport and metabolism of $\mathrm{T} 3$ and $\mathrm{T} 4$, and iii) the cell type and its pathophysiological state. Moreover, recent findings have clearly established that THs and TRs play their role by interacting with other signaling pathways in a cell-specific manner. Thus, this supplementary level of complexity also needs to be taken into account to explain their diverse and often opposing functions.

The evidence supporting a highly conserved role of THs signaling in different species strongly highlights its fundamental importance in organ physiology. Genome-wide analyses have greatly helped to define in detail the molecular signature depending on the THs and the specific TR subtype present in the different organ targets. However, our basic knowledge is still incomplete, and we need a better definition of the THs-TRs "interactome" to fully elucidate their functions in different contexts. This information may have important repercussions in TH-related pathologies. In fact, by developing TR $\alpha$ or TR $\beta$ specific agonists and antagonists, we could use them for targeted therapeutic use. In this respect, it is worth noting the current availability of specific agonists for TR $\beta 1$ such as GC-1 and KB2115 (rev. in Baxter and Webb, 2009; Malm et al., 2009). They display beneficial effects on cholesterol and lipid metabolism, but lack the side effects typical of T3 on hearth and skeleton (Johansson et al., 2005; Berkenstam et al., 2008). More importantly, in the case of KB2115, human trials have begun, thereby indicating its safety and efficacy (Berkenstam et al., 2008). In contrast, the development of TR $\alpha 1$ specific antagonists has been less advanced, despite that they could be potentially beneficial to treat arrhythmias or in preventing bone loss (rev. in O'Shea et al., 2006). In addition, other potential applications for TR $\alpha 1$ antagonists have been suggested by our studies regarding the control of intestinal progenitor proliferation by this receptor. Hence, it is worth speculating potential therapeutic use of these inhibitors for blocking pathological 
cell proliferation in intestinal tumors by specifically targeting stem and progenitor cells that exclusively express the TR $\alpha 1$ receptor.

\section{Acknowledgments}

We gratefully acknowledge Julien Nadjar for his excellent technical help and for his art work and Dr. M. Sirakov for critically reading the manuscript. We received financial support from the European Network of Excellence CRESCENDO. 


\section{References}

Abel, E.D., R.S. Ahima, M.E. Boers, J.K. Elmquist, and F.E. Wondisford. 2001. Critical role for thyroid hormone receptor beta 2 in the regulation of paraventricular thyrotropin-releasing hormone neurons. J Clin Invest. 107:1017-23.

Adachi, T., H. Takanaga, Y. Sakurai, M. Ishido, M. Kunimoto, and H. Asou. 2002. Influence of cell density and thyroid hormone on glial cell development in primary cultures of embryonic rat cerebral hemisphere. J Neurosci Res. 69:61-71.

Alisi, A., I. Demori, S. Spagnuolo, E. Pierantozzi, E. Fugassa, and S. Leoni. 2005. Thyroid status affects rat liver regeneration after partial hepatectomy by regulating cell cycle and apoptosis. Cell Physiol Biochem. 15:69-76.

Alvarez-Dolado, M., J.M. Gonzalez-Sancho, J. Bernal, and A. Munoz. 1998. Developmental expression of the tenascin-C is altered by hypothyroidism in the rat brain. Neuroscience. 84:309-22.

Alvarez-Dolado, M., A. Cuadrado, C. Navarro-Yubero, P. Sonderegger, A.J. Furley, J. Bernal, and A. Munoz. 2000. Regulation of the L1 cell adhesion molecule by thyroid hormone in the developing brain. Mol Cell Neurosci. 16:499-514.

Aniello, F., D. Couchie, A.M. Bridoux, D. Gripois, and J. Nunez. 1991a. Splicing of juvenile and adult tau mRNA variants is regulated by thyroid hormone. Proc Natl Acad Sci U S A. 88:4035-9.

Aniello, F., D. Couchie, D. Gripois, and J. Nunez. 1991b. Regulation of five tubulin isotypes by thyroid hormone during brain development. J Neurochem. 57:1781-6.

Auso E, Lavado-Autric R, Cuevas E, Del Rey FE, Morreale De Escobar G, Berbel P. 2004. A moderate and transient deficiency of maternal thyroid function at the beginning of fetal neocorticogenesis alters neuronal migration. Endocrinology 145: 4037-4047.

Baas, D., C. Legrand, J. Samarut, and F. Flamant. 2002. Persistence of oligodendrocyte precursor cells and altered myelination in optic nerve associated to retina degeneration in mice devoid of all thyroid hormone receptors. Proc Natl Acad Sci U S A. 99:2907-11.

Bafico, A., A. Gazit, T. Pramila, P.W. Finch, A. Yaniv, and S.A. Aaronson. 1999. Interaction of frizzled related protein (FRP) with Wnt ligands and the frizzled receptor suggests alternative mechanisms for FRP inhibition of Wnt signaling. J Biol Chem. 274:16180-7.

Baxter, J.D., P. Webb. 2009. Thyroid hormone mimetics: potential applications in atherosclerosis, obesity and type 2 diabetes. Nat Rev Drug Discov. 8(4):308-20.

Benvenuti, S., P. Luciani, I. Cellai, C. Deledda, S. Baglioni, R. Saccardi, S. Urbani, F. Francini, R. Squecco, C. Giuliani, G.B. Vannelli, M. Serio, A. Pinchera, and A. Peri. 2008. Thyroid hormones promote cell differentiation and up-regulate the expression of the seladin1 gene in in vitro models of human neuronal precursors. J Endocrinol. 197:437-46.

Berbel, P., A. Guadano-Ferraz, M. Martinez, J.A. Quiles, R. Balboa, and G.M. Innocenti. 1993. Organization of auditory callosal connections in hypothyroid adult rats. Eur J Neurosci. 5:1465-78.

Berbel, P., A. Guadano-Ferraz, A. Angulo, and J. Ramon Cerezo. 1994. Role of thyroid hormones in the maturation of interhemispheric connections in rats. Behav Brain Res. 64:914.

Berkenstam A, Kristensen J, Mellstrom K, Carlsson B, Malm J, Rehnmark S, Garg N, Andersson CM, Rudling M, Sjoberg F, Angelin B, Baxter JD. 2008. The thyroid hormone mimetic compound KB2115 lowers plasma LDL cholesterol and stimulates bile acid synthesis without cardiac effects in humans. Proc Natl Acad Sci USA 105: 663-667.

Bernal J, Guadano-Ferraz A, Morte B. 2003. Perspectives in the study of thyroid hormone action on brain development and function. Thyroid 13: 1005-1012.

Bernal, J. 2005. Thyroid hormones and brain development. Vitam Horm. 71:95-122. 
Bernal J. 2007. Thyroid hormone receptors in brain development and function. Nat Clin Pract Endocrinol Metab 3: 249-259.

Bianco, A.C. 2008. Metabolic effects of thyroid hormones-beyond traditional prospects. Thyroid. 18:99-100.

Bianco, A.C., and B.W. Kim. 2006. Deiodinases: implications of the local control of thyroid hormone action. J Clin Invest. 116:2571-9.

Billon, N., C. Jolicoeur, Y. Tokumoto, B. Vennstrom, and M. Raff. 2002. Normal timing of oligodendrocyte development depends on thyroid hormone receptor alpha 1 (TRalpha1). EMBO J. 21:6452-60.

Billoni, N., B. Buan, B. Gautier, O. Gaillard, Y.F. Mahe, and B.A. Bernard. 2000. Thyroid hormone receptor beta1 is expressed in the human hair follicle. Br J Dermatol. 142:645-52.

Blanpain, C., and E. Fuchs. 2006. Epidermal stem cells of the skin. Annu Rev Cell Dev Biol. 22:339-73.

Bockhorn, M., A. Frilling, T. Benko, J. Best, S.Y. Sheu, M. Trippler, J.F. Schlaak, and C.E. Broelsch. 2007. Tri-iodothyronine as a stimulator of liver regeneration after partial and subtotal hepatectomy. Eur Surg Res. 39:58-63.

Bovolenta, P., P. Esteve, J.M. Ruiz, E. Cisneros, and J. Lopez-Rios. 2008. Beyond Wnt inhibition: new functions of secreted Frizzled-related proteins in development and disease. $\mathrm{J}$ Cell Sci. 121:737-46.

Bradley DJ, Towle HC, Young WS III. 1992. Spatial and temporal expression of alpha- and beta-thyroid hormone receptor mRNAs, including the beta 2-subtype, in the developing mammalian nervous system. J Neurosci. 12: 2288-2302.

Briscoe, J., and P. Therond. 2005. Hedgehog signaling: from the Drosophila cuticle to anticancer drugs. Dev Cell. 8:143-51.

Brittan, M., and N.A. Wright. 2004. The gastrointestinal stem cell. Cell Prolif. 37:35-53.

Brown, D.D., and L. Cai. 2007. Amphibian metamorphosis. Dev Biol. 306:20-33.

Buchholz, D.R., R.A. Heimeier, B. Das, T. Washington, and Y.B. Shi. 2007. Pairing morphology with gene expression in thyroid hormone-induced intestinal remodeling and identification of a core set of TH-induced genes across tadpole tissues. Dev Biol. 303:57690.

Calza, L., D. Forrest, B. Vennstrom, and T. Hokfelt. 2000. Expression of peptides and other neurochemical markers in hypothalamus and olfactory bulb of mice devoid of all known thyroid hormone receptors. Neuroscience. 101:1001-12.

Cao XY, Jiang XM, Dou ZH, Rakeman MA, Zhang ML, O'Donnell K, Ma T, Amette K, Delong N, Delong GR. 1994. Timing of vulnerability of the brain to iodine deficiency in endemic cretinism. N Engl J Med. 331: 1739-1744.

Cao, X., F. Kambe, and H. Seo. 2005. Requirement of thyrotropin-dependent complex formation of protein kinase A catalytic subunit with inhibitor of \{kappa\}B proteins for activation of p65 nuclear factor- $\{$ kappa $\}$ B by tumor necrosis factor- $\{$ alpha $\}$. Endocrinology. 146:1999-2005.

Chandrasekaran, C., C.M. Coopersmith, and J.I. Gordon. 1996. Use of normal and transgenic mice to examine the relationship between terminal differentiation of intestinal epithelial cells and accumulation of their cell cycle regulators. J Biol Chem. 271:28414-21.

Chassande, O., A. Fraichard, K. Gauthier, F. Flamant, C. Legrand, P. Savatier, V. Laudet, and J. Samarut. 1997. Identification of transcripts initiated from an internal promoter in the cerbA alpha locus that encode inhibitors of retinoic acid receptor-alpha and triiodothyronine receptor activities. Mol Endocrinol. 11:1278-90.

Chassande, O. 2003. Do unliganded thyroid hormone receptors have physiological functions? J Mol Endocrinol. 31:9-20. 
Cho, S.W., S.J. Her, H.J. Sun, O.K. Choi, J.Y. Yang, S.W. Kim, S.Y. Kim, and C.S. Shin. 2008. Differential effects of secreted frizzled-related proteins (sFRPs) on osteoblastic differentiation of mouse mesenchymal cells and apoptosis of osteoblasts. Biochem Biophys Res Commun. 367:399-405.

Clevers, H. 2006. Wnt/beta-catenin signaling in development and disease. Cell. 127:469-80.

Columbano, A., M. Pibiri, M. Deidda, C. Cossu, T.S. Scanlan, G. Chiellini, S. Muntoni, and G.M. Ledda-Columbano. 2006. The thyroid hormone receptor-beta agonist GC-1 induces cell proliferation in rat liver and pancreas. Endocrinology. 147:3211-8.

Cuevas E, Auso E, Telefont M, Morreale de Escobar G, Sotelo C, Berbel P. 2005. Transient maternal hypothyroxinemia at onset of corticogenesis alters tangential migration of medial ganglionic eminence-derived neurons. Eur J Neurosci 22: 541-551.

Davis, P.J., A. Shih, H.Y. Lin, L.J. Martino, and F.B. Davis. 2000. Thyroxine promotes association of mitogen-activated protein kinase and nuclear thyroid hormone receptor (TR) and causes serine phosphorylation of TR. J Biol Chem. 275:38032-9.

Davis, P.J., J.L. Leonard, and F.B. Davis. 2008. Mechanisms of nongenomic actions of thyroid hormone. Front Neuroendocrinol. 29:211-8.

Dellovade TL, Chan J, Vennstrom B, Forrest D, Pfaff DW. 2000. The two thyroid hormone receptor genes have opposite effects on estrogen-stimulated sex behaviors. Nat Neurosci 3: 472-475.

Dentice, M., C. Luongo, S. Huang, R. Ambrosio, A. Elefante, D. Mirebeau-Prunier, A.M. Zavacki, G. Fenzi, M. Grachtchouk, M. Hutchin, A.A. Dlugosz, A.C. Bianco, C. Missero, P.R. Larsen, and D. Salvatore. 2007. Sonic hedgehog-induced type 3 deiodinase blocks thyroid hormone action enhancing proliferation of normal and malignant keratinocytes. Proc Natl Acad Sci U S A. 104:14466-71.

Diez D, Grijota-Martinez C, Agretti P, De Marco G, Tonacchera M, Pinchera A, de Escobar GM, Bernal J, Morte B. 2008. Thyroid hormone action in the adult brain: gene expression profiling of the effects of single and multiple doses of triiodo-L-thyronine in the rat striatum. Endocrinology .149(8):3989-4000.

Dong H, Yauk CL, Rowan-Carroll A, You SH, Zoeller RT, Lambert I, Wade MG. 2009. Identification of thyroid hormone receptor binding sites and target genes using ChIP-on-chip in developing mouse cerebellum. PLoS One .4(2):e4610.

Duan, X., E. Kang, C.Y. Liu, G.L. Ming, and H. Song. 2008. Development of neural stem cell in the adult brain. Curr Opin Neurobiol. 18:108-15.

Dumitrescu AM, Liao XH, Best TB, Brockmann K, Refetoff S. 2004. A novel syndrome combining thyroid and neurological abnormalities is associated with mutations in a monocarboxylate transporter gene. Am J Hum Genet 74: 168-175.

Dumitrescu AM, Liao XH, Weiss RE, Millen K, Refetoff S. 2006. Tissue-specific thyroid hormone deprivation and excess in monocarboxylate transporter (mct) 8-deficient mice. Endocrinology 147: 4036-4043.

Durand, B., and M. Raff. 2000. A cell-intrinsic timer that operates during oligodendrocyte development. Bioessays. 22:64-71.

Erdogan, M., Y.S. Ilhan, M.A. Akkus, S.A. Caboglu, I. Ozercan, N. Ilhan, and M. Yaman. 1999. Effects of L-thyroxine and zinc therapy on wound healing in hypothyroid rats. Acta Chir Belg. 99:72-7.

Faergemann, J., T. Sarnhult, E. Hedner, B. Carlsson, T. Lavin, X.H. Zhao, and X.Y. Sun. 2002. Dose-response effects of tri-iodothyroacetic acid (Triac) and other thyroid hormone analogues on glucocorticoid-induced skin atrophy in the haired mouse. Acta Derm Venereol. 82:179-83.

Farwell, A.P., and S.A. Dubord-Tomasetti. 1999a. Thyroid hormone regulates the expression of laminin in the developing rat cerebellum. Endocrinology. 140:4221-7. 
Farwell, A.P., and S.A. Dubord-Tomasetti. 1999b. Thyroid hormone regulates the extracellular organization of laminin on astrocytes. Endocrinology. 140:5014-21.

Fink, C.W., J.L. Ferguson, and J.D. Smiley. 1967. Effect of hyperthyroidism and hypothyroidism on collagen metabolism. J Lab Clin Med. 69:950-9.

Flamant, F., A.L. Poguet, M. Plateroti, O. Chassande, K. Gauthier, N. Streichenberger, A. Mansouri, and J. Samarut. 2002. Congenital hypothyroid Pax8(-/-) mutant mice can be rescued by inactivating the TRalpha gene. Mol Endocrinol. 16:24-32.

Flamant, F., and J. Samarut. 2003. Thyroid hormone receptors: lessons from knockout and knock-in mutant mice. Trends Endocrinol Metab. 14:85-90.

Forrest D, Sjoberg M, Vennstrom B. 1990. Contrasting developmental and tissue-specific expression of alpha and beta thyroid hormone receptor genes. EMBO J 9: 1519-1528.

Forrest D, Hallbook F, Persson H, Vennstrom B. 1991. Distinct functions for thyroid hormone receptors alpha and beta in brain development indicated by differential expression of receptor genes. EMBO J 10: 269-275.

Forrest, D., L.C. Erway, L. Ng, R. Altschuler, and T. Curran. 1996. Thyroid hormone receptor beta is essential for development of auditory function. Nat Genet. 13:354-7.

Francavilla, A., B.I. Carr, A. Azzarone, L. Polimeno, Z. Wang, D.H. Van Thiel, V. Subbotin, J.G. Prelich, and T.E. Starzl. 1994. Hepatocyte proliferation and gene expression induced by triiodothyronine in vivo and in vitro. Hepatology. 20:1237-41.

Fredric, E., and M. Wondisford. 2004. Lessons learned from TR-beta mutant mice. In Syndromes of hormone resistance on the hypothalamic-pituitary-thyroid axis. P. BeckPeccoz, editor. Kluwer Academic Publishers. 109-118.

Freedberg, I.M., M. Tomic-Canic, M. Komine, and M. Blumenberg. 2001. Keratins and the keratinocyte activation cycle. J Invest Dermatol. 116:633-40.

Freund, J.N., C. Domon-Dell, M. Kedinger, and I. Duluc. 1998. The Cdx-1 and Cdx-2 homeobox genes in the intestine. Biochem Cell Biol. 76:957-69.

Friesema EC, Grueters A, Biebermann H, Krude H, von Moers A, Reeser M, Barrett TG, Mancilla EE, Svensson J, Kester MH, Kuiper GG, Balkassmi S, Uitterlinden AG, Koehrle J, Rodien P, Halestrap AP, Visser TJ. 2004. Association between mutations in a thyroid hormone transporter and severe X-linked psychomotor retardation. Lancet 364: 1435-1437.

Fu, L., A. Tomita, H. Wang, D.R. Buchholz, and Y.B. Shi. 2006. Transcriptional regulation of the Xenopus laevis Stromelysin-3 gene by thyroid hormone is mediated by a DNA element in the first intron. J Biol Chem. 281:16870-8.

Gauthier, K., M. Plateroti, C.B. Harvey, G.R. Williams, R.E. Weiss, S. Refetoff, J.F. Willott, V. Sundin, J.P. Roux, L. Malaval, M. Hara, J. Samarut, and O. Chassande. 2001. Genetic analysis reveals different functions for the products of the thyroid hormone receptor alpha locus. Mol Cell Biol. 21:4748-60.

Guigon, C.J., L. Zhao, C. Lu, M.C. Willingham, and S.Y. Cheng. 2008. Regulation of betacatenin by a novel nongenomic action of thyroid hormone beta receptor. Mol Cell Biol. 28:4598-608.

Haddow JE, Palomaki GE, Allan WC, Williams JR, Knight GJ, Gagnon J, O'Heir CE, Mitchell ML, Hermos RJ, Waisbren SE, Faix JD, Klein RZ. 1999. Maternal thyroid deficiency during pregnancy and subsequent neuropsychological development of the child. N Engl J Med 341: 549-555.

Hadj-Sahraoui, N., I. Seugnet, M.T. Ghorbel, and B. Demeneix. 2000. Hypothyroidism prolongs mitotic activity in the post-natal mouse brain. Neurosci Lett. 280:79-82.

Hanley, K., K.R. Feingold, L.G. Komuves, P.M. Elias, L.J. Muglia, J.A. Majzoub, and M.L. Williams. 1998. Glucocorticoid deficiency delays stratum corneum maturation in the fetal mouse. J Invest Dermatol. 111:440-4. 
Harvey CB, Bassett JH, Maruvada P, Yen PM, Williams GR. 2007. The rat thyroid hormone receptor (TR) Deltabeta3 displays cell-, TR isoform-, and thyroid hormone response element-specific actions. Endocrinology 148: 1764-1773.

Hasebe, T., M. Kajita, Y.B. Shi, and A. Ishizuya-Oka. 2008. Thyroid hormone-up-regulated hedgehog interacting protein is involved in larval-to-adult intestinal remodeling by regulating sonic hedgehog signaling pathway in Xenopus laevis. Dev Dyn. 237:3006-15.

Hashimoto, H., N. Shintani, K. Tanaka, W. Mori, M. Hirose, T. Matsuda, M. Sakaue, J. Miyazaki, H. Niwa, F. Tashiro, K. Yamamoto, K. Koga, S. Tomimoto, A. Kunugi, S. Suetake, and A. Baba. 2001. Altered psychomotor behaviors in mice lacking pituitary adenylate cyclase-activating polypeptide (PACAP). Proc Natl Acad Sci U S A. 98:1335560.

Henning, S., D. Rubin, and J. Shulman. 1994. Ontogeny of the intestinal mucosa. In Physiology of the Gastrointestinal Tract. J. LR, editor. Raven Press, New York. 571-601.

Heuer H, Maier MK, Iden S, Mittag J, Friesema EC, Visser TJ, Bauer K.2005. The monocarboxylate transporter 8 linked to human psychomotor retardation is highly expressed in thyroid hormone-sensitive neuron populations. Endocrinology 146: 1701-1706.

Hindmarsh P. 2002. Optimisation of thyroxine dose in congenital hypothyroidism. Arch Dis Child 86: 73-75.

Hiroi, Y., H.H. Kim, H. Ying, F. Furuya, Z. Huang, T. Simoncini, K. Noma, K. Ueki, N.H. Nguyen, T.S. Scanlan, M.A. Moskowitz, S.Y. Cheng, and J.K. Liao. 2006. Rapid nongenomic actions of thyroid hormone. Proc Natl Acad Sci U S A. 103:14104-9.

Horsley, V. 1885. The Brown Lectures on Pathology. Br Med J. 1:111-115.

Hrytsiuk I, Gilbert R, Logan S, Pindora S, Brook CG. 2002. Starting dose of levothyroxine for the treatment of congenital hypothyroidism: a systematic review. Arch Pediatr Adolesc Med 156: 485-491.

Iglesias, T., J. Caubin, H.G. Stunnenberg, A. Zaballos, J. Bernal, and A. Munoz. 1996. Thyroid hormone-dependent transcriptional repression of neural cell adhesion molecule during brain maturation. EMBO J. 15:4307-16.

Ishizuya-Oka, A., Q. Li, T. Amano, S. Damjanovski, S. Ueda, and Y.B. Shi. 2000. Requirement for matrix metalloproteinase stromelysin-3 in cell migration and apoptosis during tissue remodeling in Xenopus laevis. J Cell Biol. 150:1177-88.

Ishizuya-Oka, A., S. Ueda, T. Inokuchi, T. Amano, S. Damjanovski, M. Stolow, and Y.B. Shi. 2001. Thyroid hormone-induced expression of sonic hedgehog correlates with adult epithelial development during remodeling of the Xenopus stomach and intestine. Differentiation. 69:27-37.

Ishizuya-Oka A, Shimizu K, Sakakibara S, Okano H, Ueda S. 2003. Thyroid hormoneupregulated expression of Musashi-1 is specific for progenitor cells of the adult epithelium during amphibian gastrointestinal remodeling. J Cell Sci. 116(Pt 15):3157-64.

Ishizuya-Oka, A., and Y.B. Shi. 2005. Molecular mechanisms for thyroid hormone-induced remodeling in the amphibian digestive tract: a model for studying organ regeneration. Dev Growth Differ. 47:601-7.

Ishizuya-Oka, A., and T. Hasebe. 2008. Sonic hedgehog and bone morphogenetic protein-4 signaling pathway involved in epithelial cell renewal along the radial axis of the intestine. Digestion. 77 Suppl 1:42-7.

Ishizuya-Oka A, Hasebe T, Buchholz DR, Kajita M, Fu L, Shi YB. 2009. Origin of the adult intestinal stem cells induced by thyroid hormone in Xenopus laevis. FASEB J. Mar 19, ahead of publication.

Jansen, J., E.C. Friesema, C. Milici, and T.J. Visser. 2005. Thyroid hormone transporters in health and disease. Thyroid. 15:757-68. 
Johansson L, Rudling M, Scanlan TS, Lundasen T, Webb P, Baxter J, Angelin B, Parini P. 2005. Selective thyroid receptor modulation by GC-1 reduces serum lipids and stimulates steps of reverse cholesterol transport in euthyroid mice. Proc Natl Acad Sci USA 102: 10297- 10302.

Jumarie, C., and C. Malo. 1994. Alkaline phosphatase and peptidase activities in Caco-2 cells: differential response to triiodothyronine. In Vitro Cell Dev Biol Anim. 30A:753-60.

Kaneshige, M., K. Kaneshige, X. Zhu, A. Dace, L. Garrett, T.A. Carter, R. Kazlauskaite, D.G. Pankratz, A. Wynshaw-Boris, S. Refetoff, B. Weintraub, M.C. Willingham, C. Barlow, and S. Cheng. 2000. Mice with a targeted mutation in the thyroid hormone beta receptor gene exhibit impaired growth and resistance to thyroid hormone. Proc Natl Acad Sci U S A. 97:13209-14.

Kim, C.S., V.V. Vasko, Y. Kato, M. Kruhlak, M. Saji, S.Y. Cheng, and M.D. Ringel. 2005. AKT activation promotes metastasis in a mouse model of follicular thyroid carcinoma. Endocrinology. 146:4456-63.

Klein, I., and K. Ojamaa. 2001. Thyroid hormone and the cardiovascular system. N Engl J Med. 344:501-9.

Koenig, R.J., M.A. Lazar, R.A. Hodin, G.A. Brent, P.R. Larsen, W.W. Chin, and D.D. Moore. 1989. Inhibition of thyroid hormone action by a non-hormone binding c-erbA protein generated by alternative mRNA splicing. Nature. 337:659-61.

Koibuchi N, Chin WW. 2000. Thyroid hormone action and brain development. Trends Endocrinol Metab 11: 123-128.

Komuves, L.G., K. Hanley, Y. Jiang, P.M. Elias, M.L. Williams, and K.R. Feingold. 1998. Ligands and activators of nuclear hormone receptors regulate epidermal differentiation during fetal rat skin development. J Invest Dermatol. 111:429-33.

Koster, M.I., and D.R. Roop. 2007. Mechanisms regulating epithelial stratification. Annu Rev Cell Dev Biol. 23:93-113.

Kress, E., A. Rezza, J. Nadjar, J. Samarut, and M. Plateroti. 2009. The frizzled-related sFRP2 gene is a target of thyroid hormone receptor alphal and activates beta-catenin signaling in mouse intestine. J Biol Chem. 284:1234-41.

Laudet, V., C. Hanni, J. Coll, F. Catzeflis, and D. Stehelin. 1992. Evolution of the nuclear receptor gene superfamily. Embo J. 11:1003-13.

Lazar MA. 2003. Thyroid hormone action: a binding contract. J Clin Invest. 112(4): 497-499.

Ledda-Columbano, G.M., A. Perra, M. Pibiri, F. Molotzu, and A. Columbano. 2005. Induction of pancreatic acinar cell proliferation by thyroid hormone. J Endocrinol. 185:3939.

Lemkine, G.F., A. Raj, G. Alfama, N. Turque, Z. Hassani, O. Alegria-Prevot, J. Samarut, G. Levi, and B.A. Demeneix. 2005. Adult neural stem cell cycling in vivo requires thyroid hormone and its alpha receptor. FASEB J. 19:863-5.

Leneman M, Buchanan L, Rovet J. 2001. Where and what visuospatial processing in adolescents with congenital hypothyroidism. J Int Neuropsychol Soc 7: 556-562.

Lennox, J., and I.D. Johnston. 1973. The effect of thyroid status on nitrogen balance and the rate of wound healing after injury in rats. Br J Surg. 60:309.

Lima, F.R., N. Goncalves, F.C. Gomes, M.S. de Freitas, and V. Moura Neto. 1998. Thyroid hormone action on astroglial cells from distinct brain regions during development. Int $\mathrm{J}$ Dev Neurosci. 16:19-27.

Lima, F.R., A. Gervais, C. Colin, M. Izembart, V.M. Neto, and M. Mallat. 2001. Regulation of microglial development: a novel role for thyroid hormone. J Neurosci. 21:2028-38.

Lin, H.Y., A. Shih, F.B. Davis, and P.J. Davis. 1999. Thyroid hormone promotes the phosphorylation of STAT3 and potentiates the action of epidermal growth factor in cultured cells. Biochem J. 338 ( Pt 2):427-32. 
Lorenzo, P.I., C. Menard, F.D. Miller, and J. Bernal. 2002. Thyroid hormone-dependent regulation of Talpha1 alpha-tubulin during brain development. Mol Cell Neurosci. 19:33343.

Lucio RA, Garcia JV, Ramon Cerezo J, Pacheco P, Innocenti GM, Berbel P. 1997. The development of auditory callosal connections in normal and hypothyroid rats. Cereb Cortex 7: 303-316.

Lynch, J., M. Keller, R.J. Guo, D. Yang, and P. Traber. 2003. Cdx1 inhibits the proliferation of human colon cancer cells by reducing cyclin D1 gene expression. Oncogene. 22:6395407.

Malik, R., N. Mellor, C. Selden, and H. Hodgson. 2003. Triiodothyronine enhances the regenerative capacity of the liver following partial hepatectomy. Hepatology. 37:79-86.

Malm J., Färnegârdh M, Grover GJ, Ladenson PW. 2009. Thyroid Hormone Antagonists: Potential Medical Applications and Structure Activity Relationships. Curr Med Chem. 2009 Sep 1. [Epub ahead of print].

Mansouri, A., K. Chowdhury, and P. Gruss. 1998. Follicular cells of the thyroid gland require Pax8 gene function. Nat Genet. 19:87-90.

Manzano J, Cuadrado M, Morte B, Bernal J. 2007a. Influence of thyroid hormone and thyroid hormone receptors in the generation of cerebellar gamma-aminobutyric acid-ergic interneurons from precursor cells. Endocrinology. 148(12):5746-51.

Manzano J, Bernal J, Morte B 2007b Influence of thyroid hormones on maturation of rat cerebellar astrocytes. Int J Dev Neurosci 25:171-179.

Marshall JA, Dixon KE. 1978. Cell specialization in the epithelium of the small intestine of feeding Xenopus laevis tadpoles. J Anat. 126(Pt 1):133-44.

Matosin-Matekalo, M., J.E. Mesonero, T.J. Laroche, M. Lacasa, and E. Brot-Laroche. 1999. Glucose and thyroid hormone co-regulate the expression of the intestinal fructose transporter GLUT5. Biochem J. 339 ( Pt 2):233-9.

Mehregan, A.H., and P. Zamick. 1974. The effect of triiodothyronine in healing of deep dermal burns and marginal scars of skin grafts. A histologic study. J Cutan Pathol. 1:113-6.

Mellstrom B, Naranjo JR, Santos A, Gonzalez AM, Bernal J. 1991. Independent expression of the alpha and beta c-erbA genes in developing rat brain. Mol Endocrinol 5: 1339-1350.

Miller, L.D., K.S. Park, Q.M. Guo, N.W. Alkharouf, R.L. Malek, N.H. Lee, E.T. Liu, and S.Y. Cheng. 2001. Silencing of Wnt signaling and activation of multiple metabolic pathways in response to thyroid hormone-stimulated cell proliferation. Mol Cell Biol. 21:6626-39.

Morreale de Escobar G, Obregon MJ, Escobar del Rey F. 2000. Is neuropsychological development related to maternal hypothyroidism or to maternal hypothyroxinemia? J Clin Endocrinol Metab 85: 3975-3987.

Morreale de Escobar GM, Obregon MJ, del Rey FE. 2004. Maternal thyroid hormones early in pregnancy and fetal brain development. Best Pract Res Clin Endocrinol Metab 18: 225248.

Morte, B., J. Manzano, T. Scanlan, B. Vennstrom, and J. Bernal. 2002. Deletion of the thyroid hormone receptor alpha 1 prevents the structural alterations of the cerebellum induced by hypothyroidism. Proc Natl Acad Sci U S A. 99:3985-9.

Morte B, Manzano J, Scanlan TS, Vennstrom B, Bernal J 2004 Aberrant maturation of astrocytes in thyroid hormone receptor_1 knockout mice reveals an interplay between thyroid hormone receptor isoforms. Endocrinology 145:1386-1391.

Narayanan CH, Narayanan Y. 1985. Cell formation in the motor nucleus and mesencephalic nucleus of the trigeminal nerve of rats made hypothyroid by propylthiouracil. Exp Brain Res 59: 257-266. 
Newell, F.W., and K.R. Diddie. 1977. [Typical monochromacy, congenital deafness, and resistance to intracellular action of thyroid hormone (author's transl)]. Klin Monatsbl Augenheilkd. 171:731-4.

Nicholson JL, Altman J. 1972a. The effects of early hypo- and hyperthyroidism on the development of the rat cerebellar cortex. II. Synaptogenesis in the molecular layer. Brain Res. 44(1):25-36.

Nicholson JL, Altman J. 1972b. The effects of early hypo- and hyperthyroidism on the development of rat cerebellar cortex. I. Cell proliferation and differentiation. Brain Res. 144(1):13-23.

Nicholson JL, Altman J. 1972c. Synaptogenesis in the rat cerebellum: effects of early hypoand hyperthyroidism. Science. 176(34):530-2.

Nygard, M., G.M. Wahlstrom, M.V. Gustafsson, Y.M. Tokumoto, and M. Bondesson. 2003. Hormone-dependent repression of the E2F-1 gene by thyroid hormone receptors. Mol Endocrinol. 17:79-92.

Ohmura, T., S.L. Katyal, J. Locker, G.M. Ledda-Columbano, A. Columbano, and H. Shinozuka. 1997. Induction of cellular DNA synthesis in the pancreas and kidneys of rats by peroxisome proliferators, 9-cis retinoic acid, and 3,3',5-triiodo-L-thyronine. Cancer Res. 57:795-8.

Ohtsuki, M., M. Tomic-Canic, I.M. Freedberg, and M. Blumenberg. 1992. Regulation of epidermal keratin expression by retinoic acid and thyroid hormone. J Dermatol. 19:774-80.

Oppenheimer, J.H., H.L. Schwartz, C.N. Mariash, W.B. Kinlaw, N.C. Wong, and H.C. Freake. 1987. Advances in our understanding of thyroid hormone action at the cellular level. Endocr Rev. 8:288-308.

Ord, W. 1878. On myxoedema, a term proposed to be applied to an essential condition in the "cretinoid" affection occasionally observed in middle-aged women. Med Chir Trans (Lond). 61:57.

O'Shea PJ, Bassett JH, Cheng SY, Williams GR. 2006. Characterization of skeletal phenotypes of TRalpha1 and TRbeta mutant mice: implications for tissue thyroid status and T3 target gene expression. Nucl Recept Signal 4: E011.

Perez-Juste, G., and A. Aranda. 1999. The cyclin-dependent kinase inhibitor p27(Kip1) is involved in thyroid hormone-mediated neuronal differentiation. J Biol Chem. 274:5026-31.

Pibiri, M., G.M. Ledda-Columbano, C. Cossu, G. Simbula, M. Menegazzi, H. Shinozuka, and A. Columbano. 2001. Cyclin D1 is an early target in hepatocyte proliferation induced by thyroid hormone (T3). FASEB J. 15:1006-13.

Plateroti, M., O. Chassande, A. Fraichard, K. Gauthier, J.N. Freund, J. Samarut, and M. Kedinger. 1999. Involvement of T3Ralpha- and beta-receptor subtypes in mediation of T3 functions during postnatal murine intestinal development. Gastroenterology. 116:1367-78.

Plateroti, M., K. Gauthier, C. Domon-Dell, J.N. Freund, J. Samarut, and O. Chassande. 2001. Functional interference between thyroid hormone receptor alpha (TRalpha) and natural truncated TRDeltaalpha isoforms in the control of intestine development. Mol Cell Biol. 21:4761-72.

Plateroti, M., E. Kress, J.I. Mori, and J. Samarut. 2006. Thyroid hormone receptor alpha1 directly controls transcription of the beta-catenin gene in intestinal epithelial cells. Mol Cell Biol. 26:3204-14.

Pop VJ, Kuijpens JL, van Baar AL, Verkerk G, van Son MM, de Vijlder JJ, Vulsma T, Wiersinga WM, Drexhage HA, Vader HL. 1999. Low maternal free thyroxine concentrations during early pregnancy are associated with impaired psychomotor development in infancy. Clin Endocrinol (Oxf) 50: 149-155. 
Pop VJ, Brouwers EP, Vader HL, Vulsma T, van Baar AL, de Vijlder JJ. 2003. Maternal hypothyroxinaemia during early pregnancy and subsequent child development: a 3-year follow-up study. Clin Endocrinol (Oxf) 59: 282-288.

Porterfield SP, Hendrich CE. 1993. The role of thyroid hormones in prenatal and neonatal neurological development - current perspectives. Endocr Rev 14: 94-106.

Potter, G.B., J.M. Zarach, J.M. Sisk, and C.C. Thompson. 2002. The thyroid hormoneregulated corepressor hairless associates with histone deacetylases in neonatal rat brain. Mol Endocrinol. 16:2547-60.

Puzianowska-Kuznicka, M., M. Pietrzak, O. Turowska, and A. Nauman. 2006. Thyroid hormones and their receptors in the regulation of cell proliferation. Acta Biochim Pol. 53:641-50.

Qi, J.S., Y. Yuan, V. Desai-Yajnik, and H.H. Samuels. 1999. Regulation of the mdm2 oncogene by thyroid hormone receptor. Mol Cell Biol. 19:864-72.

Quignodon, L., C. Grijota-Martinez, E. Compe, R. Guyot, N. Allioli, D. Laperriere, R. Walker, P. Meltzer, S. Mader, J. Samarut, and F. Flamant. 2007. A combined approach identifies a limited number of new thyroid hormone target genes in post-natal mouse cerebellum. J Mol Endocrinol. 39:17-28.

Quignodon, L., C. Legrand, N. Allioli, A. Guadano-Ferraz, J. Bernal, J. Samarut, and F. Flamant. 2004. Thyroid hormone signaling is highly heterogeneous during pre- and postnatal brain development. J Mol Endocrinol. 33:467-76.

Refetoff, S. 2003. The syndrome of resistance to thyroid stimulating hormone. J Chin Med Assoc. 66:441-52.

Refetoff S, Dumitrescu AM. 2007. Syndromes of reduced sensitivity to thyroid hormone: genetic defects in hormone receptors, cell transporters and deiodination. Best Pract Res Clin Endocrinol Metab 21: 277-305.

Rovet J, Daneman D. 2003. Residual neurocognitive deficits in children and adolescents with congenital hypothyroidism: how can these be improved? Pediatric Drugs 5: 141-149.

Rubin, D.C. 2007. Intestinal morphogenesis. Curr Opin Gastroenterol. 23:111-4.

Ruiz-Marcos, A., P. Cartagena Abella, A. Garcia Garcia, F. Escobar del Rey, and G. Morreale de Escobar. 1988. Rapid effects of adult-onset hypothyroidism on dendritic spines of pyramidal cells of the rat cerebral cortex. Exp Brain Res. 73:583-8.

Runquist M, Alonso G. 2003 GABAergic signaling mediates the morphological organization of astrocytes in the adult rat forebrain. Glia 41:137-151.

Rusch, A., L.C. Erway, D. Oliver, B. Vennstrom, and D. Forrest. 1998. Thyroid hormone receptor beta-dependent expression of a potassium conductance in inner hair cells at the onset of hearing. Proc Natl Acad Sci U S A. 95:15758-62.

Rusch, A., L. Ng, R. Goodyear, D. Oliver, I. Lisoukov, B. Vennstrom, G. Richardson, M.W. Kelley, and D. Forrest. 2001. Retardation of cochlear maturation and impaired hair cell function caused by deletion of all known thyroid hormone receptors. J Neurosci. 21:9792800.

Safer, J.D., L.M. Fraser, S. Ray, and M.F. Holick. 2001. Topical triiodothyronine stimulates epidermal proliferation, dermal thickening, and hair growth in mice and rats. Thyroid. 11:717-24.

Safer, J.D., T.M. Crawford, L.M. Fraser, M. Hoa, S. Ray, T.C. Chen, K. Persons, and M.F. Holick. 2003. Thyroid hormone action on skin: diverging effects of topical versus intraperitoneal administration. Thyroid. 13:159-65.

Safer, J.D., T.M. Crawford, and M.F. Holick. 2004. A role for thyroid hormone in wound healing through keratin gene expression. Endocrinology. 145:2357-61.

Safer, J.D. 2005. The skin and connective tissue in hypothyroidism. In The thyroid. L.E. Braverman and R.D. Utiger, editors. Lippincott 
Safer, J.D., T.M. Crawford, and M.F. Holick. 2005. Topical thyroid hormone accelerates wound healing in mice. Endocrinology. 146:4425-30.

Salerno M, Militerni R, Bravaccio C, Micillo M, Capalbo D, Di MS, Tenore A.2002. Effect of different starting doses of levothyroxine on growth and intellectual outcome at four years of age in congenital hypothyroidism. Thyroid 12: 45-52.

Schoonover, C.M., M.M. Seibel, D.M. Jolson, M.J. Stack, R.J. Rahman, S.A. Jones, C.N. Mariash, and G.W. Anderson. 2004. Thyroid hormone regulates oligodendrocyte accumulation in developing rat brain white matter tracts. Endocrinology. 145:5013-20.

Schreiber AM, Cai L, Brown DD. 2005. Remodeling of the intestine during metamorphosis of Xenopus laevis. Proc Natl Acad Sci U S A. 102(10):3720-5.

Shi, Y.B., and W.P. Hayes. 1994. Thyroid hormone-dependent regulation of the intestinal fatty acid-binding protein gene during amphibian metamorphosis. Dev Biol. 161:48-58.

Shi, Y.B., and A. Ishizuya-Oka. 1996. Biphasic intestinal development in amphibians: embryogenesis and remodeling during metamorphosis. Curr Top Dev Biol. 32:205-35.

Shi, Y.B., and A. Ishizuya-Oka. 1997. Autoactivation of Xenopus Thyroid Hormone Receptor beta Genes Correlates with Larval Epithelial Apoptosis and Adult Cell Proliferation. J Biomed Sci. 4:9-18.

Silva, J.E., and P. Rudas. 1990. Effects of congenital hypothyroidism on microtubuleassociated protein-2 expression in the cerebellum of the rat. Endocrinology. 126:1276-82.

Singh R, Upadhyay G, Kumar S, Kapoor A, Kumar A, Tiwari M, Godbole MM. 2003. Hypothyroidism alters the expression of Bcl-2 family genes to induce enhanced apoptosis in the developing cerebellum. J Endocrinol 176: 39-465.

Stolow, M.A., and Y.B. Shi. 1995. Xenopus sonic hedgehog as a potential morphogen during embryogenesis and thyroid hormone-dependent metamorphosis. Nucleic Acids Res. 23:2555-62.

Strait KA, Schwartz HL, Perez-Castillo A, Oppenheimer JH. 1990. Relationship of c-erbA mRNA content to tissue triiodothyronine nuclear binding capacity and function in developing and adult rats. J Biol Chem 265: 10514-10521.

Su, Y., S. Damjanovski, Y. Shi, and Y.B. Shi. 1999. Molecular and cellular basis of tissue remodeling during amphibian metamorphosis. Histol Histopathol. 14:175-83.

Sugiyama D, Kusuhara H, Taniguchi H, Ishikawa S, Nozaki Y, Aburatani H, Sugiyama Y. 2003. Functional characterization of rat brain-specific organic anion transporter (Oatp14) at the blood-brain barrier: high affinity transporter for thyroxine. J Biol Chem 278: 4348943495.

Sutcliffe, J.G. 1988. The genes for myelin revisited. Trends Genet. 4:211-3.

Thompson CC, Potter GB. Thyroid hormone action in neural development. Cereb Cortex 2000; 10: 939-945.

Tinnikov, A., K. Nordstrom, P. Thoren, J.M. Kindblom, S. Malin, B. Rozell, M. Adams, O. Rajanayagam, S. Pettersson, C. Ohlsson, K. Chatterjee, and B. Vennstrom. 2002. Retardation of post-natal development caused by a negatively acting thyroid hormone receptor alpha1. EMBO J. 21:5079-87.

Tohyama K, Kusuhara H, Sugiyama Y. 2004. Involvement of multispecific organic anion transporter, Oatp14 (Slc21a14), in the transport of thyroxine across the blood-brain barrier. Endocrinology 145: 4384-4391.

Tomic, M., C.K. Jiang, H.S. Epstein, I.M. Freedberg, H.H. Samuels, and M. Blumenberg. 1990. Nuclear receptors for retinoic acid and thyroid hormone regulate transcription of keratin genes. Cell Regul. 1:965-73.

Torma, H., O. Rollman, and A. Vahlquist. 1993. Detection of mRNA transcripts for retinoic acid, vitamin D3, and thyroid hormone (c-erb-A) nuclear receptors in human skin using reverse transcription and polymerase chain reaction. Acta Derm Venereol. 73:102-7. 
Torma, H., T. Karlsson, G. Michaelsson, O. Rollman, and A. Vahlquist. 2000. Decreased mRNA levels of retinoic acid receptor alpha, retinoid $X$ receptor alpha and thyroid hormone receptor alpha in lesional psoriatic skin. Acta Derm Venereol. 80:4-9.

Trajkovic M, Visser TJ, Mittag J, Horn S, Lukas J, Darras VM, Raivich G, Bauer K, Heuer H. 2007. Abnormal thyroid hormone metabolism in mice lacking the monocarboxylate transporter 8. J Clin Invest 117: 627-635.

van de Wetering, M., E. Sancho, C. Verweij, W. de Lau, I. Oving, A. Hurlstone, K. van der Horn, E. Batlle, D. Coudreuse, A.P. Haramis, M. Tjon-Pon-Fong, P. Moerer, M. van den Born, G. Soete, S. Pals, M. Eilers, R. Medema, and H. Clevers. 2002. The beta-catenin/TCF4 complex imposes a crypt progenitor phenotype on colorectal cancer cells. Cell. 111:24150 .

Visser WE, Friesema EC, Jansen J, Visser TJ. 2007. Thyroid hormone transport by monocarboxylate transporters. Best Pract Res Clin Endocrinol Metab 21: 223-236.

Williams, G.R. 2000. Cloning and characterization of two novel thyroid hormone receptor beta isoforms. Mol Cell Biol. 20:8329-42.

Williams GR. 2008. Neurodevelopmental and Neurophysiological Actions of Thyroid Hormone. Journal of Neuroendocrinology 20, 784-794.

Wood, W.M., V.D. Sarapura, J.M. Dowding, W.W. Woodmansee, D.J. Haakinson, D.F. Gordon, and E.C. Ridgway. 2002. Early gene expression changes preceding thyroid hormone-induced involution of a thyrotrope tumor. Endocrinology. 143:347-59.

Wong R, Vasilyev VV, Ting YT, Kutler DI, Willingham MC, Weintraub BD, Cheng S. 1997. Transgenic mice bearing a human mutant thyroid hormone beta 1 receptor manifest thyroid function anomalies, weight reduction, and hyperactivity. Mol Med 3: 303-314.

Wrutniak-Cabello, C., F. Casas, and G. Cabello. 2000. The direct tri-lodothyronine mitochondrial pathway: science or mythology? Thyroid. 10:965-9.

Yazdanparast, P., B. Carlsson, A. Oikarinen, J. Risteli, and J. Faergemann. 2004. A thyroid hormone analogue, triiodothyroacetic acid, corrects corticosteroid-downregulated collagen synthesis. Thyroid. 14:345-53.

Yen, PM. 2001. Physiological and Molecular Basis of Thyroid Hormone Action. Physiol Rev 81:1097-1142.

Zamick, P., and A.H. Mehregan. 1973. Effect of 1-tri-iodothyronine on marginal scars of skin grafted burns in rats. Plast Reconstr Surg. 51:71-5.

Zhang, L., K. Blomgren, H.G. Kuhn, and C.M. Cooper-Kuhn. 2009. Effects of postnatal thyroid hormone deficiency on neurogenesis in the juvenile and adult rat. Neurobiol Dis. 34:366-74.

Zoeller RT, Rovet J. 2004. Timing of thyroid hormone action in the developing brain: clinical observations and experimental findings. J Neuroendocrinol 16: 809-818. 


\section{Figures legends}

Figure 1. Schematic representation of the various isoforms encoded by TR $\alpha$ (A) or TR $\beta$ (B) genes. These are generated by alternative splicing or use of different promoters. The pictures show the different domains involved in TR function. These include DNA-binding and hormone-binding domains specifically present in TR $\alpha 1, \operatorname{TR} \beta 1, \operatorname{TR} \beta 2$ and TR $\beta 3$ proteins, which are bona fide T3 nuclear receptors. TR $\alpha 2$ and the truncated TR $\Delta$ isoforms lack each or both domains. Other functional regions of the TRs include cofactor-binding domains (located in $\mathrm{A} / \mathrm{B}, \mathrm{D}$ and $\mathrm{E}$ ), as well as dimerization domains (located in $\mathrm{C}$ and $\mathrm{E}$ ). $\mathrm{AF}-1$ and $\mathrm{AF}-2$ domains are important for transcriptional activation.

Figure 2. Structural changes of the intestine during development. A-C) Summarizes the maturation of the intestine during amphibian metamorphosis. Under the influence of increasing levels of THs, the flat larval epithelium (A) is remodeled to form an organized compartmentalized adult epithelium (B). During this step mucosal growth is stimulated, as well as cell proliferation. The inset (C) shows the different tissue layers composing the mucosa. D-H) Display the developmental changes during intestinal maturation in the mouse. The multistratified endoderm $(\mathrm{D}, \mathrm{G})$ is remodeled to form a monostratified epithelium, which also becomes structurally compartmentalized (E,H). After birth, under the influence of various factors, including the THs, the intestinal epithelium undergoes the final steps of maturation (F). This involves crypt formation, extensive growth and increased cell proliferation. The insets $(\mathrm{G}, \mathrm{H})$ show the organization of different tissue layers composing the mucosa.

Figure 3. Schematic representation of the adult mammalian small intestine. The picture illustrates the mucosal structure, the different tissues and the diverse epithelial cell types. The intestinal epithelium is organized into proliferative compartments -the crypts-, where stem and progenitor cells are located, and villi where are present differentiated cells. It is worth noting the presence of Paneth cells at the bottom of crypts. They are the only differentiated cytotype present in this compartment. Connective and smooth muscle tissues are other components of the intestinal mucosa.

Figure 4. Role of the various $\mathrm{TR} \alpha$ isoforms in the control of intestinal epithelial cell proliferation and/or cell differentiation at weaning. The TR $\alpha 1$ receptor stimulates cell proliferation, while the TR $\Delta \alpha$ isoforms are negative regulators of cell proliferation and differentiation. The different effects of the TR $\alpha$ isoforms depend on the level of their respective expression. TR $\Delta \alpha$ proteins are destabilized by TR $\alpha 1$, and TR $\alpha 1$ responsiveness to T3 can be blocked by the TR $\Delta \alpha$ proteins. This mutual control guarantees normal mucosa growth and functionality.

Figure 5. Model of action of the TR $\alpha 1$ receptor on the canonical Wnt signaling pathway. A) Illustration of the widely accepted model of activation of $\mathrm{Wnt} / \beta$-catenin signaling, through the formation of a complex between Wnt/Frizzled/LRP, thereby leading to the transduction of the extracellular Wnt signal. This in turn blocks the degradation complex and stabilizes $\beta$-catenin, which shuttles to the nucleus and activates Wnt target genes, as well as epithelial proliferation. B) Our data show that TR $\alpha 1$ stimulates the expression of $\beta$-catenin and sFPR2. In the extracellular milieu, sFRP2 functionally interacts with Frizzled alone or in combination with Wnt to stabilize $\beta$-catenin and to activate target genes, as well as epithelial proliferation. 
Table 1. Proliferation-related thyroid hormones target genes in intestine of both tadpoles and mice

\section{Cell cycle control}

Gene name and (symbol)

Budding uninhibited by benzimidazoles1 homolog. b (Bub1b)

Cyclin A2 (Ccna2)

Cyclin B1 (Ccnb1)

MAD2 (mitotic arrest deficient. homolog)-like 1 (Mad2l1)

Transforming. acidic coiled-coil containing protein 3 (Tacc3)

\section{Cell Signaling \& Transcriptional regulation}

\section{Gene name and (symbol)}

\section{BMP}

Activin A receptor type 1B (AcvrA1B)

Bone morphogenetic protein 2 (BMP2

Bone morphogenetic protein 7 (BMP7)

\section{Hedgehog}

GLI-Kruppel family member GLI2 (Gli2)

Notch

Hairy and enhancer of split 1 (Drosophila) (Hes1)

Hairy and enhancer of split 2 (Drosophila) (Hes2)

Neurogenic differentiation 1 (NeuroD1)

Notch gene homolog 1 (Drosophila) (Notch1)

Wnt

Catenin (cadherin associated protein) beta 1 (Ctnnb1)

Frizzled homolog 2 (Drosophila) (Fzd2)

Secreted frizzled-related protein 2 (sFRP2)

Wingless-related MMTV integration site 5B (Wnt5b)

\section{Other}

Centromere protein A (Cenpa)

Hepatic nuclear factor 4, alpha (Hnf4a)

MARCKS-like 1 (Marcksl1) 


\section{Figure 1}

A

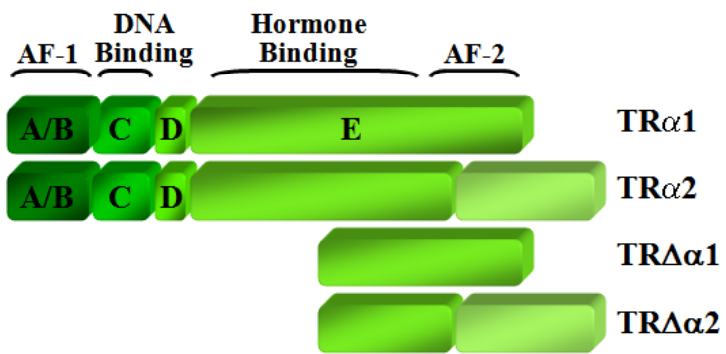

B

\begin{tabular}{|c|c|c|c|c|}
\hline AF-1 & $\begin{array}{c}\text { DNA } \\
\text { Binding }\end{array}$ & $\begin{array}{c}\text { Hormone } \\
\text { Binding } \\
\end{array}$ & AF-2 & \\
\hline $\mathbf{A} / \mathbf{B}$ & C D & $\mathbf{E}$ & & TR $\beta 1$ \\
\hline $\mathbf{A} / \mathbf{B}$ & C & E & & TR $\beta 2$ \\
\hline $\mathrm{A} / \mathrm{B}$ & $\mathrm{C}$ & E & & TR $\beta 3$ \\
\hline & & E & & TR $\Delta \beta 3$ \\
\hline
\end{tabular}


Figure 2

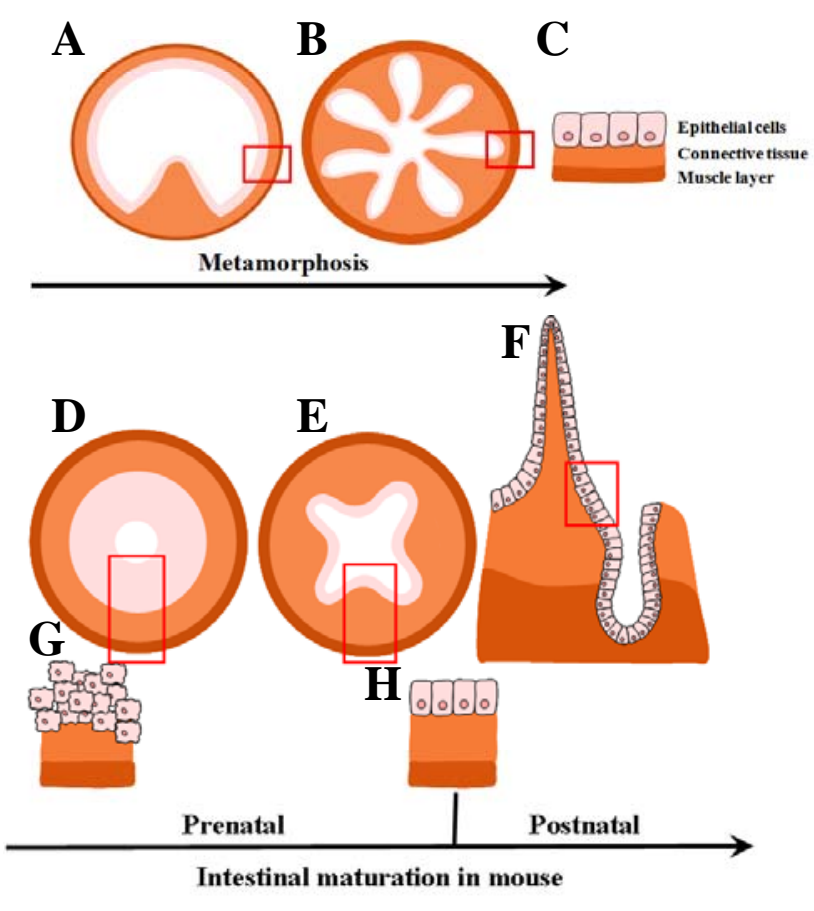




\section{Figure 3}

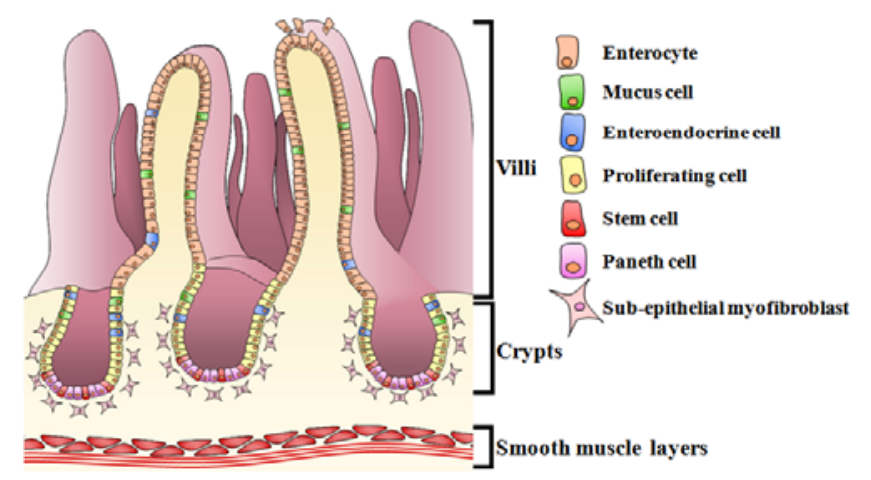


Figure 4

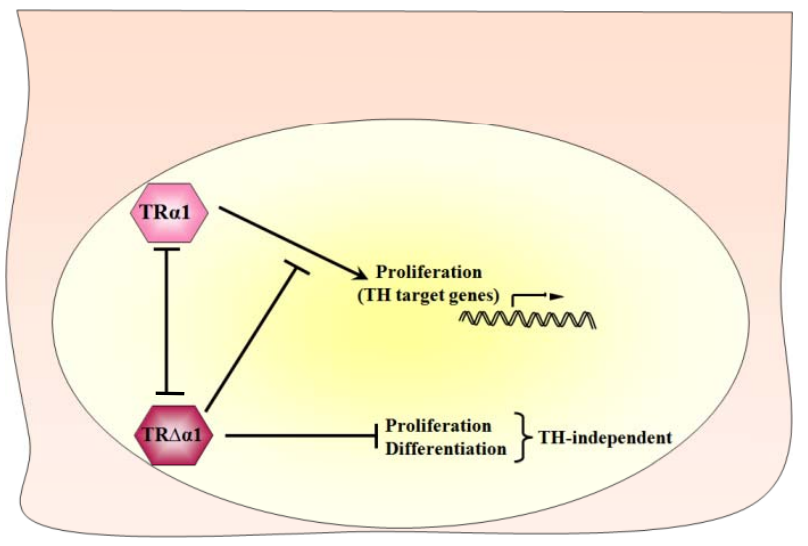




\section{Figure 5}

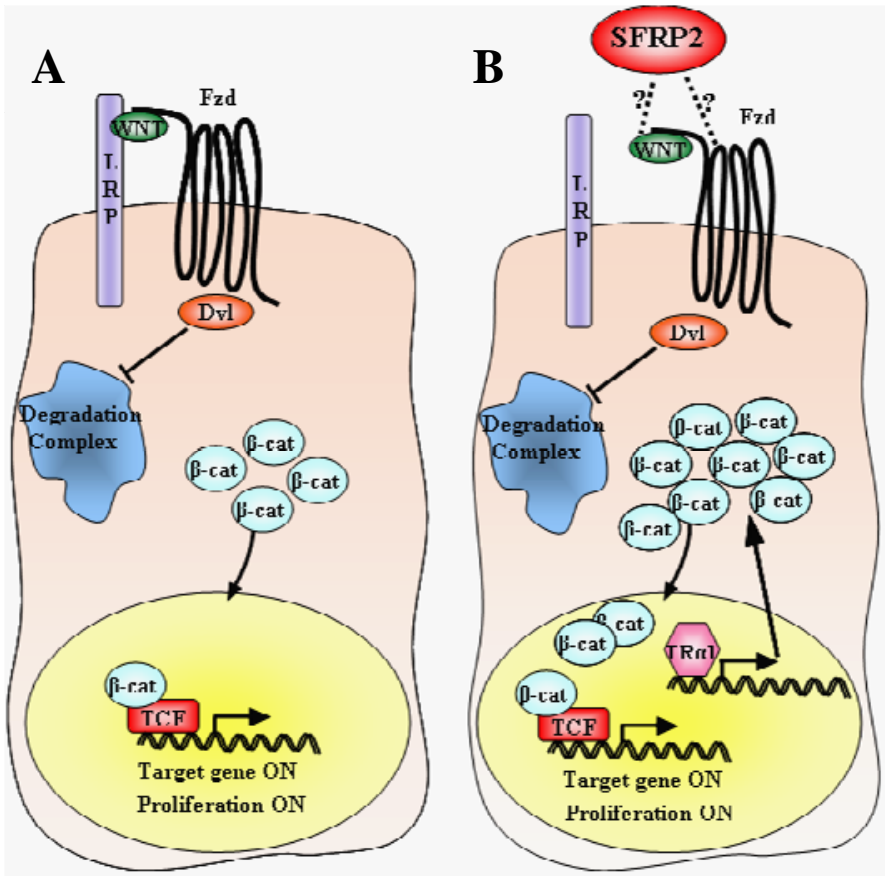

